\title{
Market discipline on bank bond issues through the lens of a new forward-looking measure of loan quality
}

\author{
Giorgia Simion $^{1}$ | Elisa Cavezzali ${ }^{2}$ | Siva Nathan ${ }^{3}$ | Ugo Rigoni ${ }^{2}$
}

${ }^{1}$ Department of Finance, Accounting and Statistics, Vienna University of Economics and Business, Vienna, Austria

${ }^{2}$ Department of Management, Ca' Foscari University of Venice San Giobbe, Venice, Italy

${ }^{3}$ School of Accountancy, J. Mack Robinson College of Business, Georgia State

University, Atlanta, Georgia

\section{Correspondence}

Siva Nathan, School of Accountancy,

J. Mack Robinson College of Business,

Georgia State University, 35 Broad St. NW, Atlanta, GA 30303, USA.

Email: snathan@gsu.edu

\begin{abstract}
Using unsecured bond spreads over the 2007 to mid2014 period, we test investors' ability to price bank loan risk. We use a new measure of loan risk that incorporates forward-looking information embedded in ratings assigned by external rating agencies to bank loan portfolios. Only Italian banks are required to systematically disclose this specific information. We find that investors do price forward-looking information inherent in bank loan portfolios. This finding reflects the increase in risk perception following the sovereign debt crisis, which had the strongest effects on peripheral countries, with tensions in the lending market. Overall, these results suggest that our new forwardlooking measure provides an additional channel through which market discipline can operate.
\end{abstract}

\section{KEY W O R D}

bank loan quality, banks, market discipline, sovereign debt crisis, unsecured bond issues

JEL CLASS I F I CA T I O N

G21

The authors would like to thank the Editor, John Doukas, and the anonymous referee for their suggestions. We would like to thank participants at the GSU Finance Department Brownbag, Finance Department Research Workshop at Syracuse University, the 2018 Financial Engineering and Banking Society (FEBS) conference, and the 2018 India Finance Conference for their comments. The authors gratefully acknowledge the Center for the Economic Analysis of Risk (CEAR) in the Robinson College of Business at Georgia State University for its financial support. We would like to dedicate this publication to Nicola Agnoletto, who left us before his time. We will remember him fondly as a friend, an excellent research assistant, and a reliable colleague. 


\section{1 | INTRODUCTION}

In this research, we examine a new forward-looking loan quality measure to study how bond market discipline has changed after the 2007 financial crisis. Effective market discipline is important, since it can reduce banks' incentives to take excessive risk and provide important signals to regulators on the soundness of banking firms. ${ }^{1}$ This requires a correct assessment of bank financial conditions that must be reflected in the price of its financial securities and cost of funding. The Basel Committee on Banking Supervision (BCBS) explicitly recognizes the relevance of market discipline as a key pillar to enhance and promote financial stability, which is expected to be reinforced with increasing disclosure requirements.

An extensive stream of research has examined bond spread-to-risk sensitivity (e.g., DeYoung, Hughes, \& Moon, 2001; Flannery \& Sorescu, 1996; Sironi, 2003), claiming that the increased use of government supports to troubled banks during the recent financial crisis has reduced unsecured investors' incentives to penalize institutions for excessive risk-taking (Acharya, Anginer, \& Warburton, 2016). Bearing in mind the importance of information disclosed to the markets, which is stressed in Pillar 3 of the Basel Capital Accord and supported by prior literature (Stephanou, 2010), we test whether disclosure of higher-quality and more relevant information helped investors to preserve and strengthen market discipline during the recent financial crisis.

Our new loan quality measure examines whether a forward-looking perspective of a bank's activities provides a more reliable and incrementally value-relevant test of market discipline. The loan portfolio is typically the largest asset on a bank's balance sheet and is commonly considered as informationally opaque. Therefore, for financial stability it is of great value to have a comprehensive and informative measure of loan risk. For this purpose, we use loan ratings supplied by external rating agencies (e.g., Standard \& Poor's Ratings Services and Moody's Investors Service) to construct a novel variable measuring the average loan portfolio risk over a 1-year horizon. More specifically, the variable is a weighted average of borrowers' external credit ratings, which convey information about their future creditworthiness, weighted based on the banks' credit exposure to the borrowers. ${ }^{2}$ This is a previously unexplored indicator of asset quality with a forward-looking focus, which better estimates the risks to which financial institutions are exposed. Prior research in this field has typically used traditional accountingbased measures of risk, with a backward-looking view (Flannery \& Sorescu, 1996; Jagtiani, Kaufman, \& Lemieux, 2002; Sironi, 2003), such as, among others, nonperforming loan ratios and loan loss reserves to nonperforming loans. These latter indicators, although informative, have a set of shortcomings. They reflect bank choices undertaken in the past that already had an impact on its performance (as such, they are ex post performance indicators), since losses have already been reported. They are also subject to the accounting discretion of banks, which can strategically manage their reporting. ${ }^{3}$

In contrast to previous research, our study attempts to examine an important channel for effective market discipline: whether bank bond spreads reflect the (ex ante) risks that banks take when granting credit (Morgan \& Stiroh, 2001). Understanding this dimension in the financial crisis context is fundamental to shedding light on the bond spread-to-risk relationship for one of the main activities that banks undertake, that is, providing funding, which expose

\footnotetext{
${ }^{1}$ Sironi (2003) defines market discipline as the ability of the market to price debt according to an issuer's risk profile.

${ }^{2}$ Further information on the variable construction is available in section 3.3.1.

${ }^{3}$ There is research that supports this argument (e.g., Hasan \& Wall, 2004).
} 
them to credit risk. Furthermore, to the best of our knowledge, we are the first to consider external ratings as ex ante measures of the quality of bank credit portfolios.

The scope of traditional risk indicators is limited and reflect different disclosure requirements. Bank accounting standards are mostly comparable across countries: Europe and many other countries endorse the IFRS principles, with the relevant exceptions of the United States, applying GAAP (even though many foreign SEC registrants use IFRS standards in their filings), Japan, with voluntary IFRS adoption allowed, and China, following Chinese Accounting Standards, which have been amended to be generally consistent with IFRS. Nevertheless, it is important to note that information disclosed through annual reports is not perfectly coincident also among countries endorsing the same standards. National rules, in fact, can require specific information disclosure in the notes to the financial statements. To the best of our knowledge, only Italian banks are required by national financial reporting regulation to disclose in their financial statements their credit risk exposure by external ratings. ${ }^{4}$ This disclosure occurs in a systematic way, across both different banks and over time. This provides a unique context to consistently construct our new forward-looking measure, which is defined as the weighted average of external ratings on the loan portfolio.

Italy is therefore an ideal setting to test whether this unexplored information of loan risk is relevant for market discipline. Furthermore, market discipline is expected to be particularly relevant for Italian banks. Italy has been one of the most adversely affected by the financial crisis (Albertazzi, Ropele, Sene, \& Signoretti, 2014) and, in Europe, Italian banks were among major issuers of bonds (Grasso, Linciano, Pierantoni, \& Siciliano, 2010).

Over the 2007 to mid-2014 period, we gather data on unsecured bond issues from the 15 largest Italian banks which were the target of the 2014 asset quality review (AQR) performed by the European Central Bank (ECB). These banks together account for almost $87 \%$ of the Italian banking system total assets. The remaining share includes smaller banks that either do not issue bonds or issue only a marginal fraction of bonds over our time frame. We focus on this time interval as it is characterized by a large use of bonds as source of funding for (mainly) large banks. Furthermore, it follows the first release in 2005 of a regulation by the Bank of Italy entitled 'Banks' Financial Statements: Layout and Preparation." This regulation, beside adopting the IAS/IFRS standards, introduces a richer disclosure of financial information that banks are required to produce, where, among other items, information on external ratings is included for the first time. We hand-collect this data from the notes to the financial statements. The analysis was then conducted in two stages. First, we examine whether our forward-looking variable of asset risk, together with standard bank risk measures, is incrementally priced by market participants. Second, we test whether market discipline has changed from the pre- to the post-sovereign debt crisis period by performing a structural break analysis and then repeating the first stage analysis for two sub-periods.

For the entire time interval of our study, we find that the bond market incrementally prices the forward-looking information reflected in bank loan portfolios. Further analyses show that this result is primarily driven by the time period following the sovereign debt crisis. Our

\footnotetext{
${ }^{4}$ We examined the annual reports of the 15 largest US banks and a representative dataset of large banks from other (non-Italian) EU countries. With respect to the former, none of the banks disclosed any information like the forwardlooking information on loan risk that is disclosed by Italian banks. With respect to the latter, we found that some banks disclose related information, but this information is neither homogenous among banks of the same country or systematic over time.

${ }^{5}$ This regulation is known as Bank of Italy Circular no. 262 and was issued on 22 December 2005.
} 
interpretation of this finding is that the European sovereign debt crisis has heightened investors' risk awareness and in response they used an enhanced measure of asset risk to price bank bonds. Our results hold when controlling for a comprehensive set of bank risk dimensions and, most importantly, when accounting for implicit government guarantees.

This research provides two incremental contributions to the bank bond pricing literature. First, we find that investors, when disclosure makes this possible, look beyond standard measures of banks' risk: forward-looking information of loan risk is an important, and previously unexplored, driver of bond spreads. Second, the European sovereign debt crisis has significantly affected and changed market discipline, raising awareness of bank risk. Both findings are confirmed despite potential unintended effects arising from government supports. We provide evidence that mandatory disclosure of this forward-looking information can act as an additional channel for bond market discipline. This finding addresses the current debate, which has grown over the past years, on how to support market discipline. Additional bank regulations have been introduced in this regard, such as, among others, the Dodd-Frank Act (Balasubramnian \& Cyree, 2014; Gao, Liao, \& Wang, 2018) in the United States, and, more recently, the European Union (EU) bail-in legislation (Crespi, Giacomini, \& Mascia, 2019). However, market discipline still seems to be far from its optimal level of effectiveness and additional channels need to be relied on.

The incremental contributions of this study are particularly relevant to regulators and financial institutions as well. With respect to policy implications, our results show that, for Italian banks, forward-looking information of bank loan portfolios is relevant for bank creditors. Regulators of other countries, following the Italian example, should consider requiring its disclosure. With respect to accounting standard-setting implications, this research provides insights related to IFRS 9. The International Accounting Standards Board (IASB) released IFRS 9 in July 2014 and it went into effect on 1 January 2018. It introduces an 'expected-loss impairment model that will require more timely recognition of expected credit losses' (IFRS, 2014). This will overcome the limitations of the incurred loss approach of IAS 39. Under the IFRS 9 requirement, an allowance is recorded after estimating forecasted credit losses over 1 year or the entire loan life horizon, based on the level and variation in credit risk. Expected credit losses (mandated by IFRS 9) are related to the probability of loan default, which in turn will affect the loan credit rating. Our study shows that loan rating is priced in the bond market. Therefore, we provide preliminary evidence that IFRS 9 mandated information will be useful in the pricing of bank bonds. Given this result, we expect that IFRS 9 will, ceteris paribus, foster market discipline. Finally, with respect to implications for credit institutions, our results indicate that less opaque banks could in principle improve their cost-to-risk relationship. This can be done by either disclosing external ratings, along with their corresponding risk-matched credit exposures, as examined in our research, or providing insight into internal ratings. Although Italian banks are required to disclose in the notes to the financial statement their balance sheet exposures by internal ratings, there is substantial opaqueness in this regard. Internal rating information is not comparable across banks since, in most cases, rating classes are not mapped into default probabilities. Thus, this information cannot help stakeholders in assessing loan quality among banks. Therefore, internal ratings data are not used in this research.

The rest of the paper is structured as follows. In section 2, we discuss the related literature and purpose of the research. Data and methodology are described in section 3. Our results are reported in section 4. Section 5 contains robustness checks. Finally, section 6 concludes. 


\section{2 | RELATED LITERATURE}

A large body of literature investigates the market's ability to discipline bank risk-taking (Flannery \& Sorescu, 1996; Jagtiani et al., 2002; Morgan \& Stiroh, 2000; Sironi, 2003) by analyzing whether there is a relation between measures of bank risk, generally expressed through easy-to-observe accounting ratios, and its cost of funding, after controlling for economy-wide factors. To date, prior research on market discipline shows mixed results. Several conditions are required for market discipline to be effective: investors need to perceive themselves at risk of losses in the event of bank failure; they must observe and correctly understand bank financial conditions, promptly impounding such information into the prices of risky bank debt (market monitoring). Furthermore, market signals must influence, either directly or through regulators, bank risk-taking behavior (market influencing). It is evident that these conditions are strongly related to the regulatory environment in which banks operate.

Research conducted on US banking firms prior to the mid-1980s fails to find significant spread-to-risk relationship (Avery, Belton, \& Goldberg, 1988; Gorton \& Santomero, 1990). However, as the regulation on bondholders' protection weakened in the late 1980s, investors became more sensitive to banks' risk profiles and, consequently, later studies present some evidence that bond spreads reflect the issuing bank's financial profile. Using subordinated bond data over the 1983-1991 period, Flannery and Sorescu (1996) document that yield spreads are influenced by bank accounting measures of risk and that this relation strengthens in the last years of the analysis, during which government guarantees were partially reduced. Jagtiani et al. (2002) reach similar results for the period following the passage of the Federal Deposit Insurance Corporation Improvement Act (FDICIA) of 1991, showing that the market prices credit risk, especially for less capitalized financial institutions.

Later research extends the spread-to-risk analysis to the European banking industry. Sironi (2003), using a dataset of European banks, shows that subordinated bond spreads issued from 1991 to 2000 are sensitive to accounting measures of risk and more prominently in the second part of the examined period. He argues that this increase in the bond risk sensitivity is driven by a progressive reduction in the perceived too-big-to-fail (TBTF) policies. At the country level, Gropp, Gruendl, and Guettler (2014) use the removal of government guarantees for German saving banks in 2001 as a natural experiment to test the impact of public guarantees on bank risk-taking behavior. They find that when explicit guarantees are in force, moral hazard effects occur, which can harm bank financial stability and increase the likelihood of future banking crises.

In addition to research investigating whether investors can identify and price firm-specific risk, a related literature focuses on the strength of market discipline. Morgan and Stiroh (2001) examine the relationship between subordinated bond spreads and banks' asset composition to test whether investors price 'the ex ante risks implicit in the entire mix of loans and other assets at a bank' (p. 196). Results based on US banks over the 1993-1998 period document that accounting measures of asset risk jointly explain bond spreads, suggesting that market discipline can limit excessive risk-taking. Subsequent studies further test the effectiveness of market discipline by analyzing regulatory changes (Balasubramnian \& Cyree, 2014) and implicit government guarantees (Acharya et al., 2016). This research overall documents the presence of TBTF discount on yield spreads, concluding that market discipline is less tough for the largest financial institutions. More recently, Crespi et al. (2019) have examined the market impact of the introduction of the bail-in framework, which became effective in January 2016 and substantially increased risk exposure for unsecured bondholders. Using data on Italian bank bond 
issues, they show higher funding costs for bond issues subject to the new rules in the post-2016 period as compared to those issues excluded by the regulation.

Another strand of literature concerns the timeliness and accuracy of bank regulators and investors in evaluating the soundness of banking firms. Empirical research on US banks by Berger, Davies, and Flannery (2000) and DeYoung et al. (2001) shows that both market and regulators produce useful information about the future financial conditions of banking firms but none of them have complete information on banks' risk profiles.

Whereas the literature on market discipline is vast and mainly US-oriented, there is still mixed evidence on the channels and risk factors, which reinforce and influence market discipline, especially during turbulent market conditions. To address this gap, we propose a forward-looking indicator on banks' loan risk that assesses investors' ability to account for banks' future risk, that will, in turn, influence bank future performance (ex ante performance indicator). We claim that the availability of this more relevant information amplifies the disciplinary response of unsecured bond investors. By investigating the sensitivity of Italian bank bonds to a forward-looking measure of loan portfolio risk, our paper primarily relates to the first strand of the above-mentioned literature, which focuses on market monitoring. Second, it provides insight into research on market influencing, since pricing ex ante performance measures, provides the basis for limiting bank managers' incentives for increasing risk-taking (Morgan \& Stiroh, 2000).

\section{3 | DATA AND METHODOLOGY}

\section{1 | Bank bond data}

Using Thomson Reuters, we collect data on all bond issues from the 15 largest Italian banks over the 2006-2014 period characterized by a relatively large number of issues. ${ }^{6}$

We screen banks from the comprehensive list of significant financial institutions' target of the first AQR by the ECB. Importantly, most institutions are also subject to the single supervisory mechanism (SSM) established by the ECB, which aims at monitoring the stability of important banking groups. Furthermore, among all Italian banks, only these institutions issue enough bonds to make analysis on market discipline meaningful.

To be included in the final dataset, bonds must satisfy a series of selection criteria common in prior related research: we exclude all callable, puttable, convertible, covered, floating rate bonds and, ultimately, we drop bonds with warrants and less than 1 year to maturity. The resulting procedure leads to a final dataset of 5,997 unsecured bond issues, of which 5,972 are senior and the remaining subordinated bonds.

For each fixed-rate coupon issue, we then compute the spread (Spread) at issuance defined as the difference between the yield to maturity and that of the corresponding maturity-match interest rate swap (IRS). The decision to use the swap zero curve as a benchmark risk-free rate, instead of the common Treasury zero curve, is due to three reasons. First, Italian Treasury bonds cannot be considered truly risk-free during the period under investigation as Italy, together with the other peripheral countries, has been strongly hit by the recent financial crisis, as clearly expressed by the unprecedented high 10-year

${ }^{6}$ The decision not to expand the time horizon is driven by the fact that bond issues have substantially decreased afterwards (see Figure 1). Therefore, an analysis over a longer time interval would be less relevant. 
BTP-Bund spread rates. Second, it allows for a better comparison of the two yields and thus to a more accurate spread estimate because both instruments have par value at the bond issuance date. ${ }^{7}$ On the contrary, if the bond issue date does not match that of a Treasury bond, the latter does not have par value at bond issuance date ${ }^{8}$ due to the oscillation of market prices. Third, prior literature provides empirical support for the use of the zeroswap curve as risk-free zero curve (Blanco, Brennan, \& Marsh, 2005; Hull, Predescu, \& White, 2004).

Contrary to most related studies, this research is based on primary market data. We avoid including secondary market data because the market for European and Italian bond issues is not very liquid. Moreover, bond yields at issuance express the real transaction prices and not 'approximate prices' computed by brokers or obtained from pricing metrics (Crespi et al., 2019; Sironi, 2003). Finally, from a bank perspective, bond spreads at launch are an accurate estimate of the true cost paid by financial institutions.

\section{2 | Bank representativeness and funding structure}

Table 1 displays the list of banks and the representativeness of our dataset, expressed as the ratio of total assets held by our banks over banking system total assets. ${ }^{9}$ With respect to the 2006-2014 period, coverage ranges between $72 \%$ and $88 \%$, indicating that our dataset covers a large portion of Italian banking assets. The importance of our banks is also expressed by the fact that most institutions are classified as significant supervised entities by the ECB (Table 1). The largest banks are Intesa SanPaolo and Unicredit, which together account on average for roughly $55 \%$ of banking system total assets. Significant coverage is also observed for Monte dei Paschi di Siena, Banco Popolare, and Unione di Banche Italiane, which represent on average about $16 \%$ of banking system total assets.

To better gauge the role of bank bond funding, Figure 1 displays the trend of debt securities issued over total liabilities in the 1997-2017 period, comparing Italy with EU countries. Data are obtained from the ECB Statistical Data Warehouse. ${ }^{10}$ The higher relevance of debt securities as source of funding in Italy as compared to the EU is remarkable since 2000. The Italy-EU gap significantly widens over the 2007-2012 period, as proof of the fact that this funding channel has been critical in supporting banks' activities during adverse market conditions. After 2013, the gap reduces progressively and is almost nonexistent in 2017.

Figure 2 shows the share of customer deposits in total debt securities issued for both Italian and EU banks in the 2003-2017 period. As a result of the increased wholesale funding costs triggered by the financial crisis and subsequent introduction of Basel III, customer deposits rose. Nevertheless, consistent with the higher relevance of bond funding in our context, this ratio is higher for the EU than Italy. Thereafter, with the reduction in the issuance of debt securities in Italy from 2013 onward, we observe a steady rise in the share of customer deposits over debt securities issued, which reversed the Italy-EU trend in 2016.

\footnotetext{
${ }^{7} 99 \%$ of bonds in our dataset are issued at par.

${ }^{8}$ Except if they are both issued on the same day, which is generally unlikely.

${ }^{9}$ Banking system total assets are measured using data on consolidated balance sheets obtained from the Bankscope database.

${ }^{10}$ Data are available here: http://sdw.ecb.europa.eu
} 
TA B LE 1 Coverage in terms of banking system total assets

This table reports the coverage of our dataset in terms of total banking system assets over the 2006-2014 period. More in details, for each bank we compute the ratio between total assets and total banking system assets using consolidated data from the Bankscope database. Last column denotes whether a bank is subject to the single supervisory mechanism (SSM) or not.

\begin{tabular}{|c|c|c|c|c|c|c|c|c|c|c|}
\hline Bank & 2006 & 2007 & 2008 & 2009 & 2010 & 2011 & 2012 & 2013 & 2014 & SSM \\
\hline Banca Carige SpA & $0.80 \%$ & $0.94 \%$ & $0.97 \%$ & $1.16 \%$ & $1.27 \%$ & $1.38 \%$ & $1.51 \%$ & $1.76 \%$ & $1.54 \%$ & Yes \\
\hline Banca Monte dei Paschi di Siena & $5.50 \%$ & $6.01 \%$ & $7.54 \%$ & $8.15 \%$ & $8.52 \%$ & $8.29 \%$ & $7.39 \%$ & $7.22 \%$ & $6.72 \%$ & Yes \\
\hline $\begin{array}{l}\text { Banca Popolare dell'Emilia } \\
\text { Romagna Società Cooperativa }\end{array}$ & $1.57 \%$ & $1.80 \%$ & $1.86 \%$ & $2.16 \%$ & $2.04 \%$ & $2.08 \%$ & $2.08 \%$ & $2.24 \%$ & $2.22 \%$ & Yes \\
\hline Banca Popolare di Milano & $1.39 \%$ & $1.62 \%$ & $1.59 \%$ & $1.61 \%$ & $1.89 \%$ & $1.79 \%$ & $1.77 \%$ & $1.79 \%$ & $1.77 \%$ & Yes \\
\hline $\begin{array}{l}\text { Banca Popolare di Sondrio } \\
\text { Società Cooperativa }\end{array}$ & $0.56 \%$ & $0.70 \%$ & $0.77 \%$ & $0.85 \%$ & $0.92 \%$ & $1.01 \%$ & $1.09 \%$ & $1.19 \%$ & $1.30 \%$ & Yes \\
\hline Banca Popolare di Vicenza SpA & $0.82 \%$ & $1.01 \%$ & $1.02 \%$ & $1.12 \%$ & $1.24 \%$ & $1.44 \%$ & $1.58 \%$ & $1.64 \%$ & $1.70 \%$ & Yes \\
\hline $\begin{array}{l}\text { Banco Popolare Società } \\
\text { Cooperativa }\end{array}$ & $4.15 \%$ & $4.77 \%$ & $4.28 \%$ & $4.92 \%$ & $4.72 \%$ & $4.62 \%$ & $4.45 \%$ & $4.57 \%$ & $4.51 \%$ & Yes \\
\hline Credito Emiliano & $0.84 \%$ & $0.97 \%$ & $1.06 \%$ & $0.96 \%$ & $1.05 \%$ & $1.07 \%$ & $1.04 \%$ & $1.14 \%$ & $1.27 \%$ & Yes \\
\hline Credito Valtellinese SpA & $0.52 \%$ & $0.64 \%$ & $0.83 \%$ & $0.90 \%$ & $0.93 \%$ & $0.98 \%$ & $1.01 \%$ & $0.99 \%$ & $1.06 \%$ & No \\
\hline Iccrea Holding SpA & $0.58 \%$ & $0.69 \%$ & $0.65 \%$ & $0.63 \%$ & $0.59 \%$ & $0.89 \%$ & $1.35 \%$ & $1.68 \%$ & $1.82 \%$ & Yes \\
\hline Intesa SanPaolo SpA & $20.0 \%$ & $21.2 \%$ & $22.4 \%$ & $22.6 \%$ & $22.9 \%$ & $22.0 \%$ & $22.7 \%$ & $22.7 \%$ & $23.6 \%$ & Yes \\
\hline Mediobanca SpA & $2.01 \%$ & $2.39 \%$ & $2.61 \%$ & $2.77 \%$ & $2.54 \%$ & $2.71 \%$ & $2.46 \%$ & $2.56 \%$ & $2.59 \%$ & Yes \\
\hline UniCredit SpA & $28.5 \%$ & $37.9 \%$ & $36.9 \%$ & $33.6 \%$ & $32.4 \%$ & $31.9 \%$ & $31.2 \%$ & $30.6 \%$ & $30.9 \%$ & Yes \\
\hline Unione di Banche Italiane SpA & $4.05 \%$ & $4.51 \%$ & $4.30 \%$ & $4.43 \%$ & $4.56 \%$ & $4.47 \%$ & $4.47 \%$ & $4.51 \%$ & $4.46 \%$ & Yes \\
\hline Veneto Banca scpa & $0.38 \%$ & $0.65 \%$ & $0.75 \%$ & $0.83 \%$ & $1.15 \%$ & $1.31 \%$ & $1.36 \%$ & $1.35 \%$ & $1.32 \%$ & Yes \\
\hline Total banks & $71.7 \%$ & $85.8 \%$ & $87.5 \%$ & $86.8 \%$ & $86.8 \%$ & $85.9 \%$ & $85.5 \%$ & $86.0 \%$ & $86.9 \%$ & 14 \\
\hline
\end{tabular}

\section{3 | Bank-specific risk variables}

While bank accounting information is relatively comparable worldwide, national reporting requirements impose additional information disclosure. This is the case for Italian banks that, to the best of our knowledge, are the only financial institutions required to systematically report credit risk exposure by external ratings since 2006. Bank of Italy Circular 262 of 22 December 2005, which is entitled 'Banks' Financial Statements: Layout and Preparation,' requires Italian banks to produce this specific information in the notes to the financial statement (as well as to produce the financial statements in accordance with IAS/IFRS standards).

Considering the above-mentioned backdrop, our banks' risk variables are gathered from the 2006-2012 period. Since our dataset includes both listed and unlisted banks, these variables are estimated at year-end. ${ }^{11}$ More specifically, to construct them, we rely

\footnotetext{
${ }^{11}$ Quarterly accounting data for unlisted banks are not available.
} 


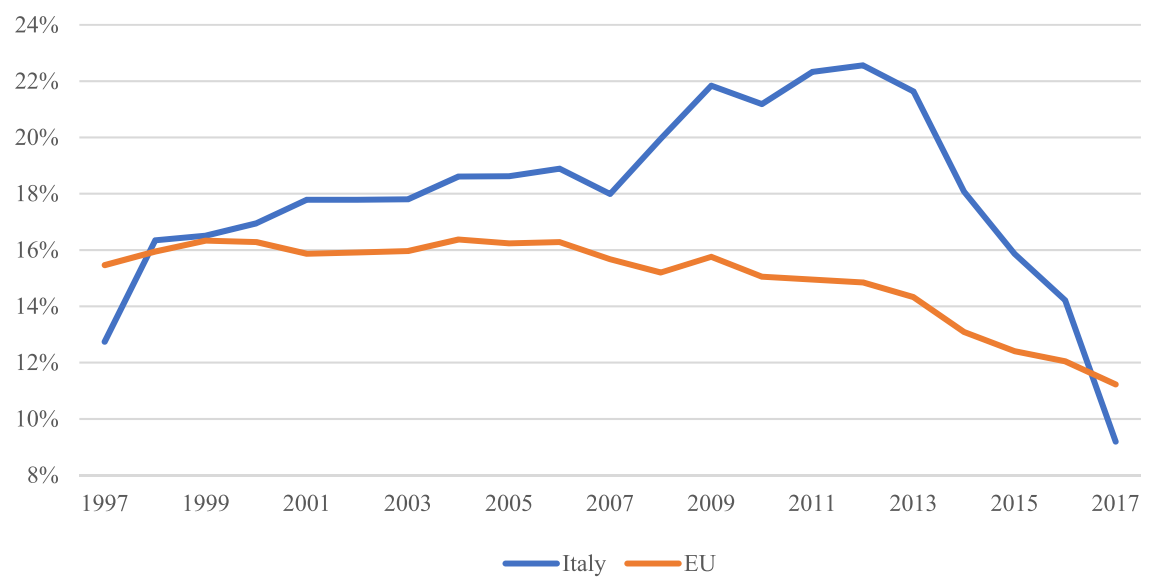

F I G URE 1 Debt securities issued over total liabilities. This figure displays the trend of debt securities issued over total liabilities for the 1997-2017 period, comparing Italy with EU countries. EU, European Union

on two sources. First, we use Bankscope, a commercial database from Bureau Van Dijk. Second, when information from Bankscope is missing, as it is the case for external rating information, we hand-collect data from the notes to the financial statements, providing a level of detail not available from standard data providers.

\subsection{1 | Forward- and backward-looking measures of loan risk}

We construct a bank loan risk indicator that incorporates forward-looking information, which so far has never been used in prior research in this area. It is possible to retrieve such information because, unlike other countries, Italian banks are required by financial reporting regulation to disclose in a table, available in the notes to the financial statements, their exposures to credit risk based on external ratings. This table breaks down bank loans by rating classes supplied by external rating agencies (e.g., Standard \& Poor's Ratings Services and Moody's Investors Service) and reports

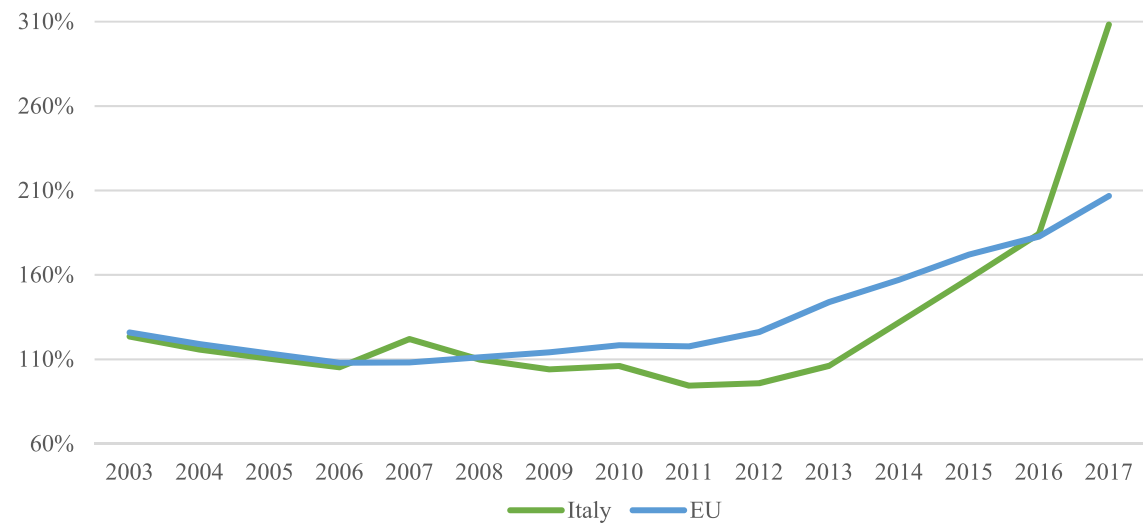

F I G URE 2 Customer deposits over total debt securities issued. This figure displays the trend of customer deposits over total debt securities issued for the 1997-2017 period, comparing Italy with EU countries. EU, European Union 
them in six credit quality classes. In the appendix we provide examples of these tables for two banks in our dataset: Intesa SanPaolo SpA and UniCredit SpA. Table 2 shows the mapping of external credit assessment institutions (ECAIs), matching external ratings to credit quality classes. Class 1 has the highest credit quality assessment, and accounts for loan ratings from AA- up to AAA, whereas class 6 has the lowest credit quality assessment, and accounts for loans with rating below $\mathrm{CCC}+$, including nonperforming loans.

The weighted average rating that can be computed from this table is an estimate of loan quality affecting bank performance and soundness in the future. More specifically, this variable assesses the average loan portfolio risk over a 1-year horizon (LPR) as follows:

$$
L P R=\frac{\sum_{i=1}^{6}\left(\text { Numericclass }_{i} * \text { Exposure }_{i}\right)}{\sum_{i=1}^{6}\left(\text { Exposure }_{i}\right)}
$$

where Numeric class $_{i}$ is the numeric value for credit quality class $i$, obtained according to Table 2. Exposure $i$ is the credit risk exposure associated to credit class $i$. This variable is then

TABLE 2 Computation of the loan portfolio risk $(L P R)$

This table reports the average loan portfolio risk $(L P R)$ computed as the weighted average of the numeric classes on the associated on-balance sheet exposures. To obtain the numeric classes, we use the mapping of external credit assessment institution (ECAI) credit ratings to credit classes. We then extend the mapping assigning to each credit rating a numeric value (i.e., numeric rating), starting from 1 for the AAA class and ending with 21 for the D class. Finally, for each credit class, we compute the arithmetic average of the numeric ratings associated to that specific class. We then repeat this procedure for all credit classes and compute numeric classes.

\begin{tabular}{|c|c|c|c|c|}
\hline & ECAI/Standard \& Poor's ratings & Numeric rating & Credit class & Numeric class \\
\hline \multirow[t]{10}{*}{ Investment grade } & AAA & 1 & \multirow[t]{4}{*}{ Class 1} & \multirow[t]{4}{*}{2.5} \\
\hline & $\mathrm{AA}+$ & 2 & & \\
\hline & AA & 3 & & \\
\hline & AA- & 4 & & \\
\hline & $\mathrm{A}+$ & 5 & \multirow[t]{3}{*}{ Class 2} & \multirow[t]{3}{*}{6} \\
\hline & $\mathrm{A}$ & 6 & & \\
\hline & A- & 7 & & \\
\hline & $\mathrm{BBB}+$ & 8 & \multirow[t]{3}{*}{ Class 3} & \multirow[t]{3}{*}{9} \\
\hline & BBB & 9 & & \\
\hline & BBB- & 10 & & \\
\hline \multirow[t]{11}{*}{ Speculative grade } & $\mathrm{BB}+$ & 11 & \multirow[t]{3}{*}{ Class 4} & \multirow[t]{3}{*}{12} \\
\hline & $\mathrm{BB}$ & 12 & & \\
\hline & BB- & 13 & & \\
\hline & $\mathrm{B}+$ & 14 & \multirow[t]{3}{*}{ Class 5} & \multirow[t]{3}{*}{15} \\
\hline & $\mathrm{B}$ & 15 & & \\
\hline & $\mathrm{B}-$ & 16 & & \\
\hline & $\mathrm{CCC}+$ & 17 & \multirow[t]{5}{*}{ Class 6} & \multirow[t]{5}{*}{19} \\
\hline & $\mathrm{CCC}$ & 18 & & \\
\hline & $\mathrm{CC}$ & 19 & & \\
\hline & $\mathrm{C}$ & 20 & & \\
\hline & $\mathrm{D}$ & 21 & & \\
\hline
\end{tabular}


constructed as the weighted average of the numeric classes (Numeric class) on the corresponding on-balance sheet exposure [Row A in the examples shown in the appendix] (Exposure). We exclude off-balance sheet credit risk exposure, since the credit equivalent amount is not reported by banks. Additional information on the construction of this variable is reported in Table 2 .

It is important to note that external rating agencies adopt standard procedures for credit quality assessment, providing an accurate and homogeneous comparison across banks. Furthermore, contrary to internal ratings that are developed by banks, external ratings, being implemented by external agencies, are free of bank management bias. ${ }^{12}$ On the downside, however, these external ratings cover only a portion of the whole credit portfolio. Most of the borrowers to which external rating agencies assign credit ratings are: governments, financial intermediaries, insurance corporations, and non-financial corporations. ${ }^{13}$ The retail sector is (usually) not rated. For our banks, coverage by external ratings is, on average, about $27 \%$ of the total credit exposure (see Table 6, Part B). To take into account this partial coverage, we also construct the rating coverage ratio $(L R C)$ as the amount of loans with an assigned rating over total gross loans. This variable captures the fraction of loan portfolio with external rating information. Because of differences in internal rating construction and lack of disclosure of internal ratings' default probability estimates across banks, we do not collect data on bank internal ratings.

For completeness, we also include standard backward-looking measures of loan risk. These variables assess decisions taken by banks in the past, whose impact on performance has already been accounted for on the annual report. Based on prior research (Sironi, 2003), we include: gross nonperforming loans to total gross loans $(B L R)$ and impairment loss on nonperforming loans to total nonperforming loans (INPL). We further introduce the ratio of impairment loss on performing loans to total performing loans (IPL), which measures the amount of allowances set aside for losses on performing loans.

\section{4 | Bank-level and bond-level risk controls}

Based on Flannery and Sorescu (1996) and Sironi (2003), we construct the following bank-level accounting controls: liquidity, leverage, return on assets, and total assets. Liquidity (LIQ) is defined as liquid assets ${ }^{14}$ to deposits and short-term funding. Leverage $(L E V)$ is the ratio of total liabilities to total equity. Return on average assets $(R O A A)$ is the ratio of year-end net income to total average assets. Assets (ASSETS) is the logarithmic transformation of total year-end assets. In addition, we develop two different measures of funding: the ratio of total loans in customer deposits and short-term funding (Loans/Fund), where a higher value indicates a higher funding gap and consequently higher likelihood to experience funding tensions, and the net stable funding ratio (NSFR), introduced by the BCBS under the new Basel III liquidity package to address funding risk. Specifically, the NSFR is designed to mitigate asset liability mismatch by requiring banks to hold a minimum amount of stable funding sources according to the risk of

\footnotetext{
${ }^{12}$ For a discussion on risk arbitrage under an internal rating system, please see Benink \& Wihlborg (2002).

${ }^{13}$ This information has been inferred from the Pillar 3 disclosures, of the Basel II accord, released by our dataset of banks.

${ }^{14}$ Based on Bankscope database, liquid assets include: trading securities, loans and advances to banks, reserve repo and cash collateral, cash and due from banks. Mandatory reserves are excluded.
} 
banks' activities. At the operational level, this index is the ratio of the available amount of stable funding to the required amount of stable funding:

$$
N S F R=\frac{\text { AvailableStableFunding }(A S F)}{\text { RequiredStableFunding }(R S F)}=\frac{\sum(\text { Sources } * \text { weightingfactor })}{\sum(\text { Uses } * \text { weightingfactor })} .
$$

The $A S F$ reflects the fraction of equity and liability financing that is expected to be a stable source of funding. More specifically, it is computed as a weighted average of bank sources on the associated weighting factor measuring the degree of solidity. The RSF instead is related to the liquidity position of a bank's activities and is obtained as a weighting average of assets on the corresponding weighting factor measuring the degree of liquidity (BCBS, 2010). We construct it (NSFR) based on the 2010 document version issued by the BCBS. Specific information and assumptions on the construction of this index are reported in Table 3.

At the bond level, we use the logarithmic transformation of total issued amounts (AMOUNT) and the time-to-maturity in years $(M A T U)$. We further include a set of dummy variables taking the value of 1 when the bond is listed (LISTED), subordinated (SUBORDINATED), is issued by the parent bank (PARENT), is offered to institutional investors (INSTITUTIONAL), and is privately placed (PRIVATE). The threshold for bond issues targeted at institutional investors has been inferred from Consob Regulation n. 11971 of 14 May 1999 and later amendments. Specifically, we use the 50,000 threshold for bonds issued before 1 July 2012 and the 100,000 threshold for bond issues afterward (as amended by Consob resolution n. 18079 of 20 January 2012 and in force from 1 July 2012).

\section{5 | Methodology}

To test bond spread sensitivity to bank asset risk, we estimate the following panel regression:

$$
\text { Spread }_{i, b, t}=\alpha+\beta \text { LoanQuality }_{i, t-\gamma}+\delta \text { BankControls }_{i, t-\gamma}+\text { BondControls }_{i, b, t}+\mu_{b}+\mu_{t}+\varepsilon_{i, a, b, t}
$$

where the dependent variable (Spread) is the spread level of bond $i$, issued by bank $b$ at time $t$. Loan Quality is a set of both forward-looking and backward-looking measures of loan riskiness. Our proposed forward-looking variable is the average loan portfolio risk over a 1-year horizon (LPR). Among traditional backward-looking measures, we use the following measures: bad loans ratio $(B L R)$, impairment loss on nonperforming loans to total nonperforming loans (INPL), and impairment loss on performing loans to total performing loans (IPL). Bank-level controls we use are the loan rating coverage ratio $(L R C)$, liquidity ( $L I Q)$, leverage ( $L E V)$, return on average assets $(R O A A)$, the logarithmic transformation of total assets (ASSETS), and the funding gap (Loans/Fund). Bond-level controls we use are bond issued amounts, logarithmically transformed $(A M O U N T)$ and maturity expressed in years $(M A T U) .{ }^{15}$ We also include a series of dummy variables taking the value of 1 for listed (LISTED), subordinated (SUBORDINATED), parent issued (PARENT), institutional (INSTITUTIONAL), and privately placed (PRIVATE) bonds (and zero otherwise). $\mu_{b}$ and $\mu_{t}$ denote bank and year fixed effects to account for common variation across bonds issued by the same bank and in the same year, respectively.

\footnotetext{
${ }^{15}$ To address the relatively few long-term bond issues, we winsorize the MATU variable at the 99th percentile value.
} 
TABLE 3 Computation of the net stable funding ratio (NSFR)

This table reports the net stable funding ratio (NSFR) as the ratio of available stable funding ( $A S F)$ to required stable funding $(R S F)$. The minimum requirement set by the Basel Committee on Banking Supervision (BCBS) is $100 \%$. This table reports accounting items, calibrating factors and assumptions based on the 2010 (NSFR) version of the index.

\section{NSFR Assumptions}

\section{Available stable funding (sources)}

Tier 1

100

Tier 2

Debt securities with residual maturity of more than 1 year

Other liabilities with residual maturity of more than 1 year

Deposits and current accounts - clientele with residual maturity more than 1 year 100

Deposits and current accounts - clientele with residual maturity less than 1 year 80

Sight deposits and current accounts - clientele 80

Deposits and current accounts - clientele of indefinite duration 80

Debt securities with residual maturity of less than 1 year 50

Required stable funding (uses)

Loans with clientele with residual maturity more than 1 year 100

Loans with banks with residual maturity more than 1 year 100

Loans with clientele with residual maturity less than 1 year 85

Loans with clientele of indefinite duration $50 \quad \# 3$

Loans with banks with residual maturity less than 6 months 0

Loans with banks with residual maturity between 6 months and 1 year

OICR shares with residual maturity more than 1 year 100 \#2

Other debt securities with residual maturity more than 1 year 50

Loans with banks of indefinite duration

0

Treasury bonds with residual maturity more than 1 year 5

\section{Main assumptions}

\#1: Clientele are classified as retail and small business customers

\#2: OICR shares are classified as unencumbered assets

\#3: Loans of indefinite duration are classified as unencumbered loans with less than 6-month term

To gauge the impact of both forward- and backward-looking measures of loan quality on the dependent variable, we include one risk category at a time in the regression specifications. To examine changes in bond spread sensitivity to bank asset risk over the 2007 to mid-2014 period, we estimate Equation (1) for the pre- and post-sovereign debt crisis period, which we set from 2 May 2010 onward, according to Ricci (2015). Because the NSFR has been introduced by the 
BCBS with the Basel III release in 2010, we include it as an alternative funding risk variable only in the post-sovereign debt crisis period.

Variables constructed from banks' annual reports are matched to the dependent variable according to a specific time criterion. Prior research generally assigns to bonds issued in year $t$ accounting measures obtained from the financial statement for the year $t-1$. However, although this standard procedure is extensively adopted, in our context it fails to correctly account for the actual information flow disclosed to investors. In the early months of year $t$ the financial statement (for the year $t-1$ ) has not yet been approved in Italy and thus it is not accessible to the public. Therefore, it is not reasonable to assume that investors base their investment decisions on as yet undisclosed information. According to the Italian regulation, bank financial statements must indeed be approved by 30 April of each year. Bearing this in mind, we construct a measure that matches bonds issued before 30 April to accounting measures obtained from the financial statement for the year $t-2$, while bonds issued after 30 April to accounting measures obtained from the financial statement for the year $t-1$. It is important to note that this lag-matching procedure corrects for any source of endogeneity. We can therefore claim that our regression model does not suffer for endogeneity issues.

We estimate Equation (1) using fixed effects panel data models with heteroskedasticityrobust standard errors clustered at the issuer level. Table 4 shows the correlation matrix among independent variables. We observe relatively low cross-sectional correlation among coefficients. For each specification of Equation (1), we also check the values of the variance inflation factor, setting 5 as threshold (this holds for all specifications).

\section{6 | Descriptive statistics}

In Table 5, we provide descriptive statistics for bond spreads and issued amounts. Until the outbreak of the crisis, bond spreads are at relatively low levels. However, in the post-2007 period, they progressively increase, reaching a peak of $2.7 \%$ in 2012 , the year in which Italy was heavily affected by the negative repercussions of the sovereign debt crisis. Over the same period, we also observe a rise in the number and amount of bonds issued. To mitigate funding concerns that emerged during the turmoil, Italian banks relied heavily on bonds as a source of funding. In 2011, the total issued amount was around $€ 41$ billion, which is more than twice the reported quantity in 2006.

Table 6 reports detailed information on regressors, while Figures 3-5 display the trend of our indicators for loan risk. One-year expectations of loan portfolio risk progressively increase starting from 2007 with an average $L P R$ of about 5, referring to a $\mathrm{A}+$ loan rating, and reaching almost the value of 9 in 2012, referring to a BBB loan rating (Figure 3). Such negative trend does not seem to stop over our time period. As previously stated, only a portion of the total credit portfolio is rated. Table 6 shows that, on average, roughly $27 \%$ of our banks' credit exposures is assigned a credit rating by external rating agencies.

With respect to standard loan risk indicators, the ratio of bad loans (Figure 4) rises from 3\% in 2006 to more than $9 \%$ in 2012. Despite deteriorating loan quality, coverage was extremely inadequate. Impairment loss on both nonperforming and performing loans exhibits a downward trend (Figure 5). More specifically, from 2007 to 2009, INPL sharply decreases, while subsequently it fluctuates around $34 \%$. Following a short increment during the first years, IPL instead diminishes from 2008 onward. 


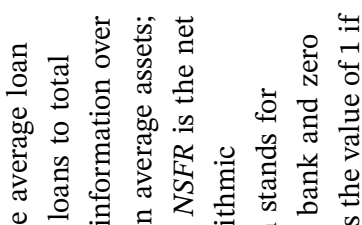

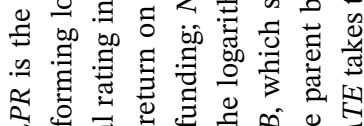

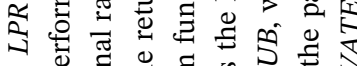

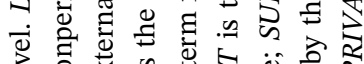

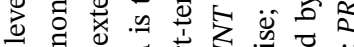
总

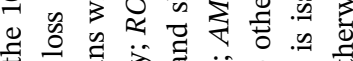

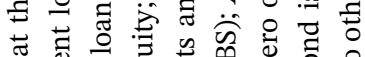

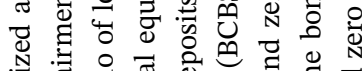

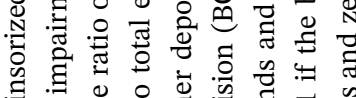

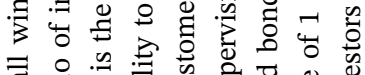

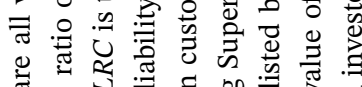
告

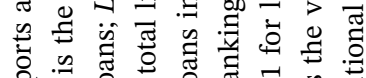

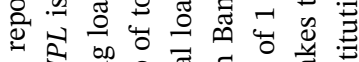

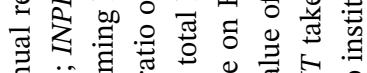

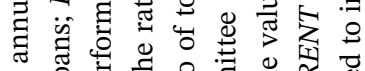

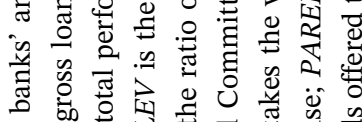

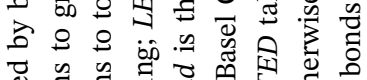

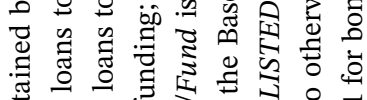

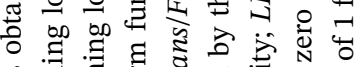

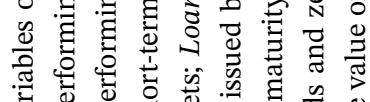
政离 政言

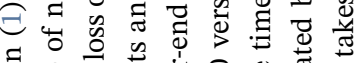

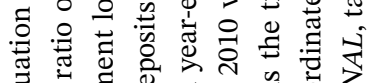

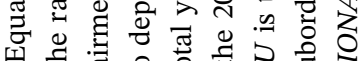

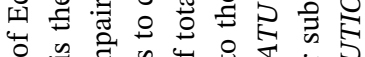

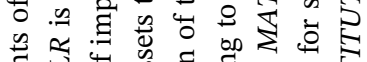

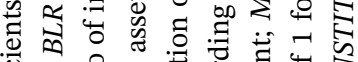

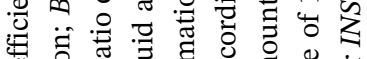

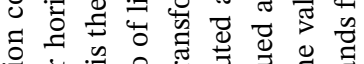

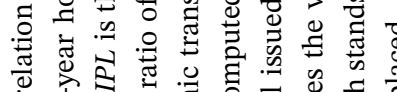

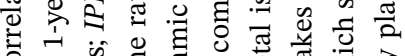
8

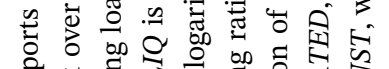

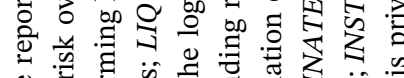

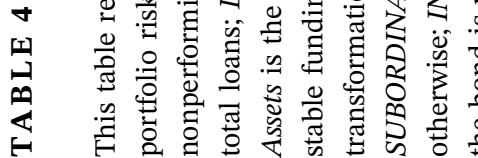

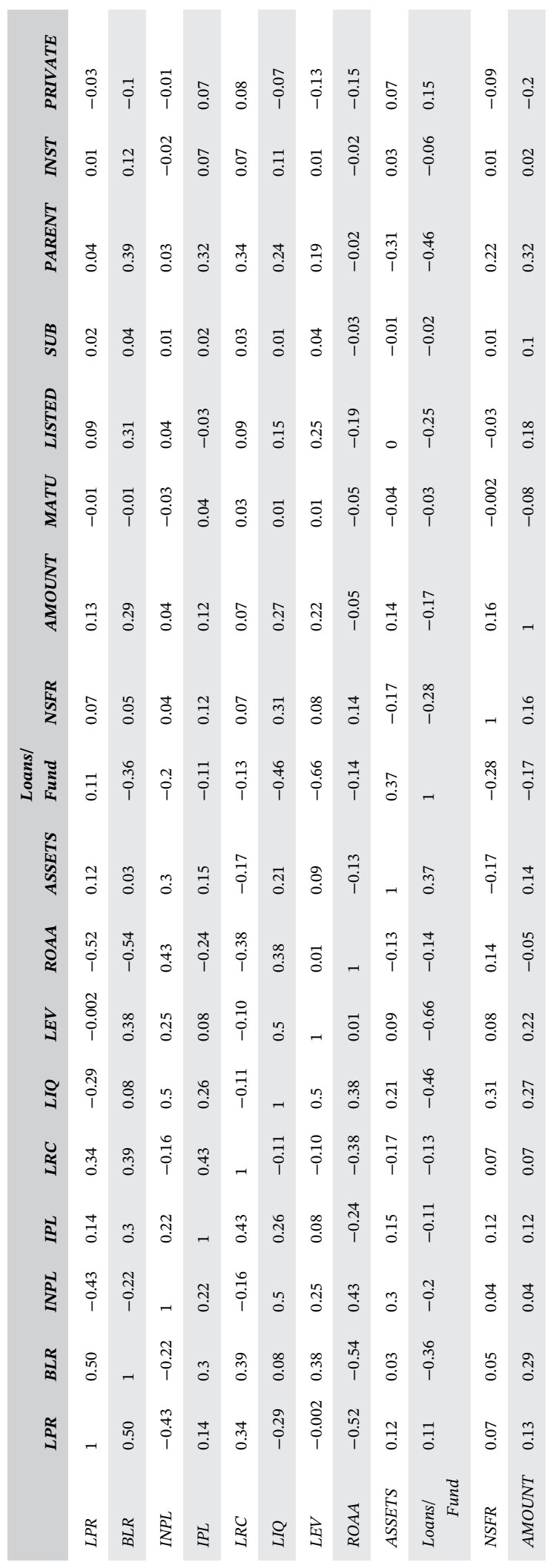




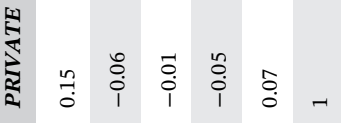

th

है

కొ

量

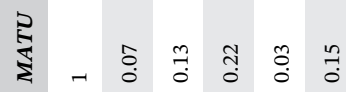

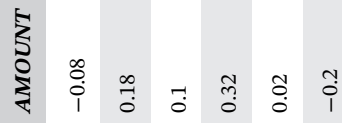

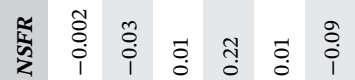

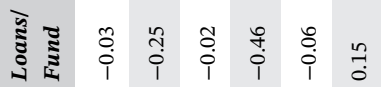

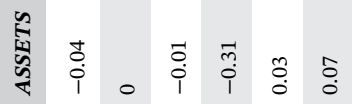

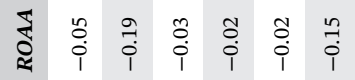

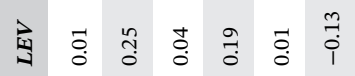

:

芩

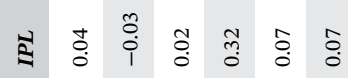

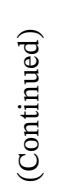

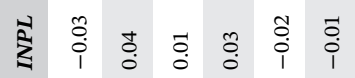

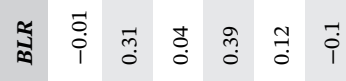

荈

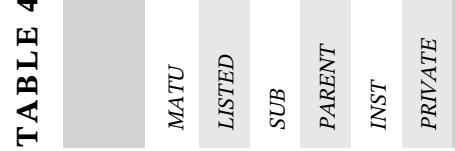


TABLE 5 Descriptive statistics - part A

This table reports descriptive statistics for bank bonds by issuing year. Spread (\%) is computed as the difference between the yield to maturity and the corresponding maturity-match interest rate swap (IRS). Amount is the amount of bonds issued (in Euro).

\begin{tabular}{|c|c|c|c|c|c|c|}
\hline \multirow[b]{2}{*}{ Year } & \multirow[b]{2}{*}{ No. of issues } & \multicolumn{2}{|c|}{ Spread (\%) } & \multicolumn{3}{|c|}{ Amount (Euro) } \\
\hline & & Mean & Standard deviation & Mean & Standard deviation & Total \\
\hline 2006 & 762 & -0.2419 & 0.647396 & $23,680,000$ & $50,157,714$ & $18,046,880,352$ \\
\hline 2007 & 763 & -0.2613 & 0.612770 & $26,550,000$ & $70,937,487$ & $20,258,320,393$ \\
\hline 2008 & 744 & 0.07560 & 0.851137 & $35,630,000$ & $124,533,967$ & $26,507,558,994$ \\
\hline 2009 & 786 & 0.6264 & 0.894504 & $48,780,000$ & $183,550,747$ & $38,341,451,472$ \\
\hline 2010 & 728 & 0.5715 & 0.790576 & $30,430,000$ & $82,004,532$ & $22,150,569,848$ \\
\hline 2011 & 971 & 1.2740 & 1.070688 & $42,580,000$ & $113,989,884$ & $41,340,703,000$ \\
\hline 2012 & 548 & 2.743 & 1.063535 & $63,300,000$ & $161,870,452$ & $34,690,474,000$ \\
\hline 2013 & 351 & 2.000 & 0.745844 & $71,930,000$ & $175,809,355$ & $25,249,078,000$ \\
\hline 2014 & 344 & 1.642 & 0.739818 & $45,530,000$ & $88,352,478$ & $15,663,813,312$ \\
\hline Total & 5,997 & 0.9354 & 1.268181 & $61,940,000$ & $122,647,476$ & $242,248,849,371$ \\
\hline
\end{tabular}

\section{4 | RESULTS}

\section{1 | Regression analysis: Baseline model}

Table 7 reports in column (1) the results from the regression analysis explaining the sensitivity of bond spreads to our new measure of loan quality $(L P R)$, controlling for bank and bond characteristics. Column (2) replaces $L P R$ with traditional measures of loan riskiness. Finally, column (3) shows the full baseline model, as expressed by Equation (1). In all cases, bankspecific variables are winsorized at the $10 \%$ level to handle potential outliers. ${ }^{16}$

The estimated coefficient of $L P R$ is always positive and highly significant, suggesting that lower expected loan portfolio quality increases bank cost of funding. Loosely speaking, our forward-looking measure of loan quality is informative and relevant in pricing bank bonds. The estimated slope coefficients in columns (1) and (3) indicate that a unit increase in loan portfolio risk (a one-notch deterioration in credit rating) increases average bond spreads by roughly 9 and 7 basis points, respectively. This a nonnegligible effect on bond spreads. Furthermore, note that the economic impact of $L P R$ does not change a lot when including in column (3) standard loan indicators, supporting the fact that our new measure of loan quality captures incremental information not explained by the latter variables. Lastly, considering that this variable reflects only a portion of the total bank's credit exposure, the high statistical significance we observe might corroborate the high relevance of the information disclosed. To some extent, $L P R$ underestimates the actual bank's credit portfolio risk, since the portfolio segment mainly captured

${ }^{16}$ Varying the level of winsorization to $5 \%$ and $1 \%$ does not change our main results from Equation (1) and all other specifications. 


\section{T A B LE 6 Descriptive statistics - part B}

This table reports descriptive statistics of the explanatory variables of Equation (1). $L P R$ is the average loan portfolio risk over a 1-year horizon; $B L R$ is the ratio of bad loans to total gross loans; $I N P L$ is the ratio of impairment loss on nonperforming loans to total nonperforming loans; IPL is the ratio of impairment loss on performing loans to total performing loans; $L R C$ is the amount of loans with an assigned rating over total gross loans; $L I Q$ is the ratio of liquid assets to deposits and short-term funding; $L E V$ is the ratio of total liabilities to total equity; $R O A A$ is the ratio of year-end net income to total average assets; Loans/Fund is the ratio between loans and deposits and short-term funding; NSFR is the net stable funding ratio computed according to the 2010 version issued by the Basel Committee on Banking Supervision (BCBS); ASSETS is the logarithmic transformation of total assets; AMOUNT is the bond issued amount, logarithmically transformed; $M A T U$ is bond maturity expressed in years; LISTED is a dummy variable for listed bonds; SUBORDINATED is a dummy variable for subordinated bonds; PARENT is a dummy variable for parent issued bonds; INSTUTIONAL is a dummy variable for bond issues targeted at institutional investors; PRIVATE is a dummy variable for privately placed bonds. Bank-specific accounting variables are all winsorized at the $10 \%$ level.

\begin{tabular}{|c|c|c|c|c|}
\hline \multirow[b]{2}{*}{ Variables } & \multirow[b]{2}{*}{ Mean } & \multicolumn{2}{|c|}{ Percentiles } & \multirow[b]{2}{*}{ Standard deviation } \\
\hline & & 25 th & 75 th & \\
\hline$L P R$ & 6.88 & 5.75 & 8.07 & 1.88 \\
\hline$B L R(\%)$ & 5.87 & 3.45 & 7.37 & 2.57 \\
\hline$I N P L(\%)$ & 35.20 & 29.28 & 38.60 & 5.95 \\
\hline$I P L(\%)$ & 0.44 & 0.38 & 0.51 & 0.10 \\
\hline $\operatorname{LRC}(\%)$ & 27.36 & 20.26 & 37.96 & 12.99 \\
\hline LIQ (\%) & 19.40 & 10.26 & 26.92 & 10.42 \\
\hline$L E V$ & 10.88 & 8.94 & 12.63 & 1.93 \\
\hline$R O A A(\%)$ & 0.44 & 0.15 & 0.76 & 0.29 \\
\hline Loans/Fund (\%) & 137.8 & 123.7 & 158.5 & 18.75 \\
\hline NSFR $(\%)$ & 101.90 & 95.26 & 107.50 & 7.49 \\
\hline ASSETS & 18.12 & 17.39 & 18.67 & 0.79 \\
\hline AMOUNT & 15.72 & 14.22 & 17.19 & 2.05 \\
\hline$M A T U$ & 3.33 & 2.00 & 3.00 & 1.89 \\
\hline LISTED & 0.07 & & & 0.59 \\
\hline SUBORDINATED & 0.004 & & & 0.06 \\
\hline PARENT & 0.52 & & & 0.50 \\
\hline INSTITUTIONAL & 0.11 & & & 0.31 \\
\hline PRIVATE & 0.05 & & & 0.21 \\
\hline
\end{tabular}

by the variable is the one of (large) borrowers. In fact, the retail sector and small and medium enterprises (SMEs) are not rated or only partially. In light of the fact that these latter segments are typically more informationally opaque than large borrowers, the effects reported in Table 7 could probably be a lower bound of the potential impact of $L P R$ on bond spreads. 


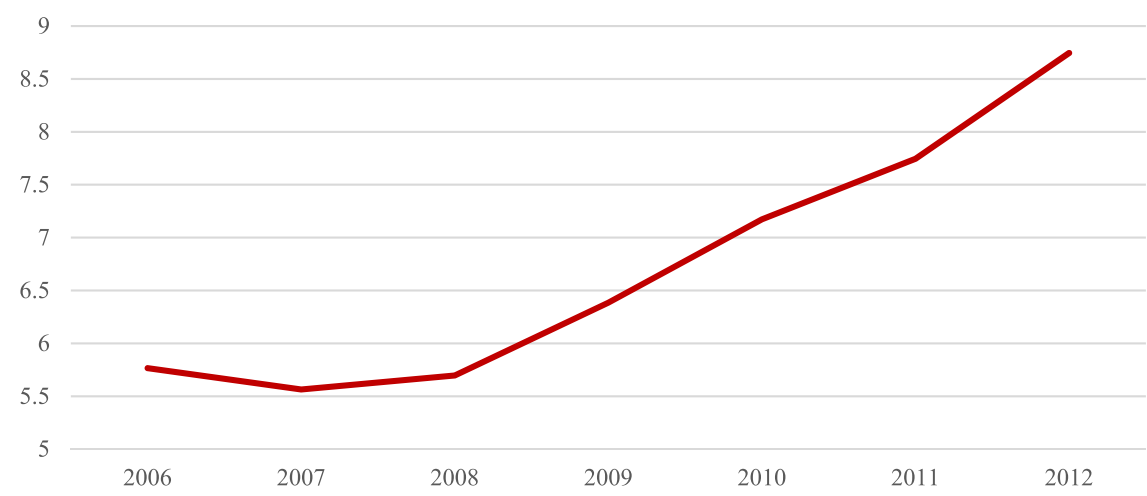

F I G U R E 3 Average loan portfolio risk (LPR) by year. This figure displays the trend of the average $L P R$ of the largest Italian banks over the 2006-2012 period

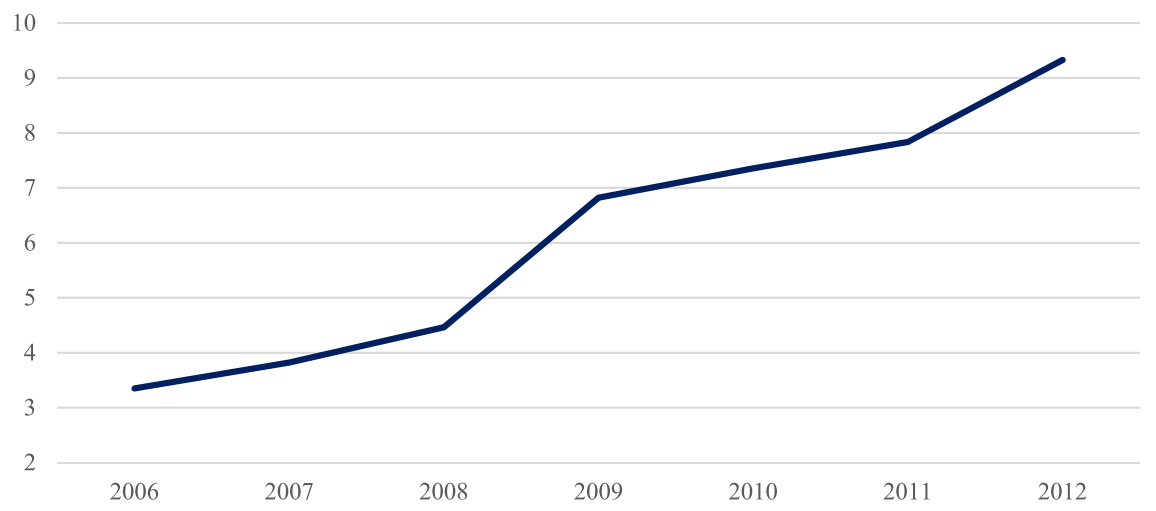

F I G U R E 4 Average bad loans ratio (BLR) (\%) by year. This figure displays the trend of the average $B L R$ of the largest Italian banks over the 2006-2012 period

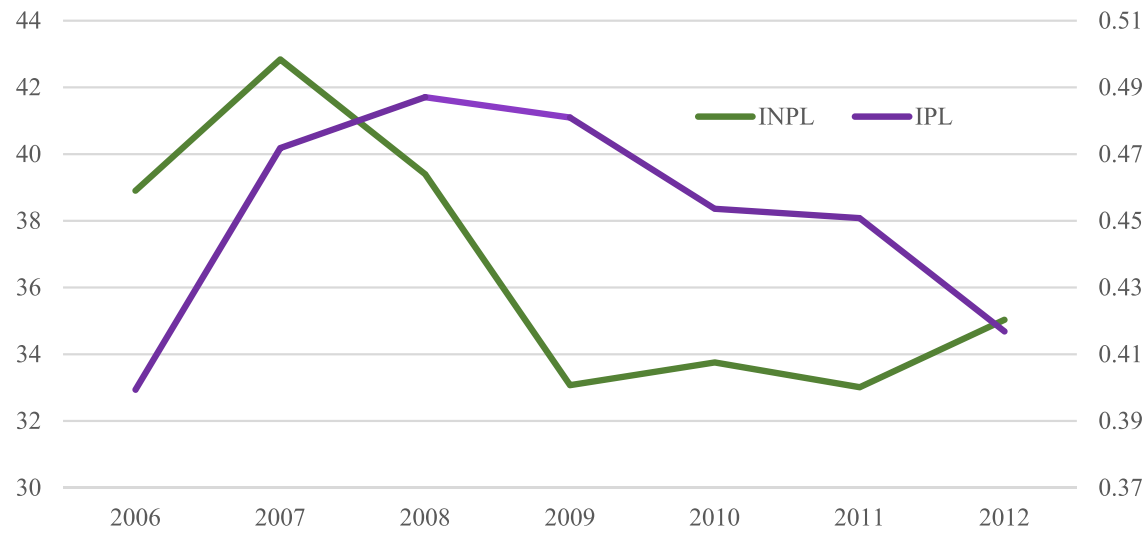

F I G U RE 5 Average coverage ratio (\%) by year. This figure displays the trend of impairment loss on nonperforming loans (INPL) and impairment loss on performing loans (IPL) of the largest Italian banks over the 2006-2012 period 
Traditional loan quality measures are important determinants of bond spreads. Consistent with prior research (Flannery \& Sorescu, 1996; Sironi, 2003), the coefficients of $B L R$ in columns (2) and (3) are positive and statistically significant: greater exposure to nonperforming loans leads to higher credit spreads. As expected, this variable has the highest effect among backward-looking loan indicators, on average. Similarly, the estimated coefficients of INPL are positive and statistically significant in both regressions. Higher allowances for nonperforming loans are not perceived by investors as a higher coverage against losses, which would result in a positive market signal, but as an indication of higher expected losses, which result in higher bond spreads, that is, negative market signal. One possible interpretation of this result is that penalizing banks with higher INPL has diminished banks' incentives to manage nonperforming loans, resulting in higher exposure to loan risk (Figures 4 and 5). Quite surprisingly, IPL reduces banks' cost of funding (columns (2) and (3)), even though it loses explanatory power in future specifications. One possible interpretation of this result is that performing loans have reduced over our time period (as a result of increasing BLR, see Figure 4). Therefore, setting aside higher allowances for the relatively small portion of loans characterized by low insolvency risk could be perceived as a prudent strategy by the market.

In terms of goodness of fit, the full model explains $52.88 \%$ of bond spread variability within a given bank, which is consistent with prior related research (Acharya et al., 2016). The reduced model in column (2) exhibits a higher goodness of fit. Note, however, that this is driven by the different number of banks included. Focusing on the specification reported in column (2), if we re-estimate the model for the 14 banks, which are also included in the full model, the goodness of fit becomes $52.60 \%$. Therefore, by adding our measure of loan quality, that is, $L P R$, the prediction accuracy of the model improves, although marginally.

With respect to bank control variables, the share of loans covered by external ratings $(L R C)$ has a negative and statistically significant coefficient in column (1), suggesting that the higher the level of transparency to investors is, the lower credit spreads are. This is consistent with the large body of banking literature that posits that informational transparency plays a key role as it reduces information asymmetries. The coefficient of the liquidity variable is always negative and statistically significant, indicating that lower liquidity risk exposure (i.e., higher $L I Q$ ) is associated with lower credit spreads. This result is consistent with Sironi (2003). Finally, the coefficients of leverage (LEV), profitability $(R O A A)$, and funding (Loans/Fund) are almost never statistically significant. Given the inclusion of relatively large banking groups, bank size (ASSETS) does not matter as well.

With respect to bond control variables, bond maturity (MATU) does not influence the dependent variable. At first glance, this result suggests that the shape of the term structure of bond spreads is not relevant to bond pricing. Research in this field has found instead this relationship to be positive, negative, or humped-shaped depending on bond features (Krylova, 2016). The outcome in Table 7 leads us to test the hypothesis of a humpedshaped relationship between bond spreads and time to maturity. Therefore, we conduct a further analysis and examine a nonlinear relationship by regressing bond spreads to time to maturity and its squared root specification to introduce the nonlinear maturity component (controlling for both time and bank fixed effects as well as bond characteristics). Unreported results provide support for this humped-shaped relationship. Specifically, medium to short-term bond issues exhibit on average a positive term structure, while longterm bond issues report a downward sloping relationship. These opposite effects cancel each other out, explaining the result for the $M A T U$ variable in Table 7. 
In Table 7, we also find that bonds that are listed (LISTED) and issued by the parent bank $(P A R E N T)$ have positive and statistically significant coefficients, ${ }^{17}$ indicating that these issues are more exposed to the discipline of the market. Given that subordinated bonds are, by definition, risker than senior bonds, the subordinated variable (SUBORDINATED) exhibits a positive and statistically significant sign in all regressions. Similarly, the coefficients of privately placed bonds (PRIVATE) exhibit in all regressions positive and statistically significant values. Since private placements are targeted at a restricted number of sophisticated and accredited investors, which are generally institutional investors in our context, individuals operating in this market have higher bargaining power and hence can obtain, ceteris paribus, higher yields. To conclude, the coefficient of the INSTITUTIONAL dummy, which captures bond issues targeted at institutional investors, is not statistically significant.

Overall, our findings support the presence of market discipline and show that investors price forward-looking information inherent in loan portfolio risk, which provides an interesting and promising outcome on the strength of market discipline (Morgan \& Stiroh, 2001).

\subsection{The nexus between $L P R$ and $L R C$}

From Table 7, we infer that the rating coverage variable $(L R C)$ has a negative effect on bond spreads, even though it loses explanatory power in the full model specification. To investigate the role of $L R C$ and whether it affects the relationship between $L P R$ and bond spreads, we performed a set of further analyses. The idea is that investors will respond differently to forward-looking information on asset risk depending on the share of credit exposure covered by external ratings.

To examine the nexus between $L P R$ and $L R C$, we first add to the baseline model their interaction. Since both variables are continuous, we perform a mean-centered transformation to ease the interpretation. We then distinguish low rating coverage from high rating coverage, as we conjecture that extreme degrees of rating coverage amplify investors' sensitivity to $L P R$. In this regard, we construct a dummy variable that takes value 1 when $L R C$ is in the fourth quartile of its sample distribution, and zero otherwise. This dummy variable, high.LRC, captures high rating coverage. Analogously, we construct a dummy variable, low. $L R C$, that takes value 1 when $L R C$ is in the first quartile of its sample distribution, and zero otherwise. This dummy variable, low.LRC, captures low rating coverage.

Table 8 reports the results of the baseline models (columns (1) and (3) of Table 7), augmented with the interaction effect. As expected, there is a positive impact of $L P R$ on bond spreads when $L R C$ is at its sample mean. The interaction term, on the other hand, is not statistically significant. The share of loan rating coverage does not seem to influence the impact of our forward-looking variable of asset risk on bond spreads.

Table 9 reports the results of the baseline models (columns (1) and (3) of Table 7), replacing LRC with the dummy variables high.LRC (columns (1) and (2)) and low.LRC (columns (3) and (4)) and interacting them with our main variable of interest, $L P R$. According to our results, the disciplinary response of $L P R$ strengthens in the top quartile of the rating coverage distribution. When coverage is high, a unit increase in $L P R$ (a one-notch deterioration in credit rating) increases bond spreads by 20 and 13 basis points on average, respectively, in columns (1) and (2)

\footnotetext{
${ }^{17}$ With the exception of the PARENT variable in column (2) of Table 7 , which is not statistically significant.
} 
TA B LE 7 Regressions of bond spreads on bank loan characteristics

This table reports the results from the regression analysis examining the spread-to-risk relationship of bond spreads over the 2007 to mid-2014 period. Spread is computed as the difference between the yield to maturity and the corresponding maturity-match interest rate swap; $L P R$ is the average loan portfolio risk over a 1-year horizon; $B L R$ is the ratio of bad loans to total gross loans; INPL is the ratio of impairment loss on nonperforming loans to total nonperforming loans; $I P L$ is the ratio of impairment loss on performing loans to total performing loans; $L R C$ is the amount of loans with an assigned rating over total gross loans; $L I Q$ is the ratio of liquid assets to deposits and short-term funding; $L E V$ is the ratio of total liabilities to total equity; $R O A A$ is the ratio of year-end net income to total average assets; Loans/Fund is the ratio between loans and deposits and short-term funding; ASSETS is the logarithmic transformation of total assets; AMOUNT is the bond issued amount, logarithmically transformed; MATU is bond maturity expressed in years; LISTED is a dummy variable for listed bonds; SUBORDINATED is a dummy variable for subordinated bonds; PARENT is a dummy variable for parent issued bonds; INSTUTIONAL is a dummy variable for bond issues targeted at institutional investors; PRIVATE is a dummy variable for privately placed bonds. Standard errors clustered at the issuer level are reported in parentheses. $* * *, * *$, and * indicate statistical significance at $1 \%, 5 \%$, and $10 \%$.

\begin{tabular}{|c|c|c|c|}
\hline Variables & (1) & (2) & (3) \\
\hline \multirow[t]{2}{*}{$L P R$} & $0.09005^{* * *}$ & & $0.07321^{* *}$ \\
\hline & {$[0.03096]$} & & {$[0.03107]$} \\
\hline \multirow[t]{2}{*}{$B L R(\%)$} & & $0.12321^{* * *}$ & $0.11812^{* * *}$ \\
\hline & & [0.02933] & {$[0.03356]$} \\
\hline \multirow[t]{2}{*}{$I N P L(\%)$} & & $0.01659^{* *}$ & $0.02301^{* * *}$ \\
\hline & & {$[0.00775]$} & {$[0.00564]$} \\
\hline \multirow{2}{*}{$I P L(\%)$} & & $-1.22229^{* * *}$ & $-1.42770^{* * *}$ \\
\hline & & {$[0.28626]$} & {$[0.49816]$} \\
\hline \multirow[t]{2}{*}{$\operatorname{LRC}(\%)$} & $-0.00971^{* * *}$ & & -0.00451 \\
\hline & {$[0.00257]$} & & {$[0.00382]$} \\
\hline \multirow[t]{2}{*}{ LIQ (\%) } & $-0.02401^{* * *}$ & $-0.02451^{* * *}$ & $-0.02682^{* * *}$ \\
\hline & {$[0.00882]$} & {$[0.00697]$} & {$[0.00789]$} \\
\hline \multirow[t]{2}{*}{$L E V$} & 0.04043 & $0.05719^{*}$ & 0.03878 \\
\hline & {$[0.03855]$} & {$[0.03102]$} & {$[0.03679]$} \\
\hline \multirow[t]{2}{*}{$R O A A(\%)$} & 0.3273 & 0.17440 & $0.28918^{*}$ \\
\hline & {$[0.2055]$} & {$[0.12484]$} & {$[0.14953]$} \\
\hline \multirow[t]{2}{*}{ Loans/Fund (\%) } & 0.00195 & 0.0045 & 0.00458 \\
\hline & {$[0.00576]$} & {$[0.00439]$} & {$[0.00488]$} \\
\hline \multirow[t]{2}{*}{ ASSETS } & 0.34106 & 0.11017 & 0.22951 \\
\hline & {$[0.22204]$} & {$[0.1752]$} & {$[0.22463]$} \\
\hline \multirow[t]{2}{*}{ AMOUNT } & -0.12808 & -0.11403 & -0.13365 \\
\hline & {$[0.09269]$} & {$[0.08933]$} & {$[0.09172]$} \\
\hline \multirow[t]{2}{*}{$M A T U$} & -0.03675 & -0.02806 & -0.04159 \\
\hline & {$[0.02474]$} & {$[0.02603]$} & {$[0.02616]$} \\
\hline \multirow[t]{2}{*}{ LISTED } & $0.4735^{* *}$ & $0.38768^{* *}$ & $0.44253^{* *}$ \\
\hline & [0.20349] & [0.19025] & [0.19694] \\
\hline
\end{tabular}


TABLE 7 (Continued)

\begin{tabular}{|llll|}
\hline Variables & $\mathbf{( 1 )}$ & $\mathbf{( 2 )}$ & $\mathbf{( 3 )}$ \\
\hline SUBORDINATED & $1.28854^{* * *}$ & $1.27121^{* * *}$ & $1.24988^{* * *}$ \\
\hline PARENT & {$[0.32213]$} & {$[0.34413]$} & {$[0.32183]$} \\
\hline INSTITUTIONAL & $0.39116^{* *}$ & 0.26064 & $0.38136^{* *}$ \\
& {$[0.18013]$} & {$[0.16042]$} & {$[0.17615]$} \\
\hline PRIVATE & 0.20505 & 0.19332 & 0.19764 \\
& {$[0.15958]$} & {$[0.13827]$} & {$[0.14686]$} \\
\hline \# of banks & $0.46445^{* * *}$ & $0.45222^{* * *}$ & $0.45362^{* * *}$ \\
\hline \# of observations & {$[0.11906]$} & {$[0.13645]$} & {$[0.11724]$} \\
\hline Adjusted $R$-squared & 14 & 15 & 14 \\
\hline Year FE & 3,966 & 4,604 & 3,888 \\
\hline
\end{tabular}

of Table 9. We therefore document that extremely high rating coverage generates a sizable effect of $L P R$ on bond spreads.

As for the low.LRC variable, we do not find any effect. Despite this evidence, our $L P R$ variable remains highly significant both in columns (3) and (4) of Table 9, corroborating the fact that this disciplinary channel matters, even when rating coverage is in the low quartile of its sample distribution.

The results in Table 9 show that in determining bank bond spreads, investors put a higher weight on external credit ratings of the banks' borrowers when the credit ratings cover a larger proportion of the banks' total loan portfolio (a proxy for information transparency).

\section{3 | Pre- and post-sovereign debt crisis}

Funding conditions of Italian (and European) banks deteriorated significantly in the second half of 2011, triggered by tensions in the sovereign debt market. The BTP-Bund spread reached its peak of roughly 550 basis points as of November 2011. From the bank side, bond issues reduced and their pricing deteriorated, reaching the highest level in 2012. Furthermore, deposits from households and nonfinancial companies flowed out and US money market fund investments reached a zero level (Bank for International Settlements (BIS), 2012). To tackle these funding strains, the ECB decided in December 2011 to implement unconventional measures to supply funding to European banks. Banks in exchange had to post collateral, with a wider than previously range of eligible assets. The 2- and 3-year long-term refinancing operations (LTROs) allotted EUR 489 billion to 523 banks (on 21 December 2011) and EUR 529 billion to 800 banks (on 29 February 2012), respectively. Italian banks were among the ones that requested the highest allocation, which reflected the strong funding pressures they were facing. These liquidity injunctions, indeed, helped them to mitigate the negative repercussions of the sovereign debt crisis, fulfilling their debt obligations and liquidity needs. 
TABLE 8 The nexus between $L P R$ and $L R C$ - part A

This table reports the results from the regression analysis examining the spread-to-risk relationship of bond spreads over the 2007 to mid-2014 period. Spread is computed as the difference between the yield to maturity and the corresponding maturity-match interest rate swap; $L P R$ is the average loan portfolio risk over a 1-year horizon; $B L R$ is the ratio of bad loans to total gross loans; INPL is the ratio of impairment loss on nonperforming loans to total nonperforming loans; IPL is the ratio of impairment loss on performing loans to total performing loans; $L R C$ is the amount of loans with an assigned rating over total gross loans; $L I Q$ is the ratio of liquid assets to deposits and short-term funding; $L E V$ is the ratio of total liabilities to total equity; $R O A A$ is the ratio of year-end net income to total average assets; ASSETS is the logarithmic transformation of total assets; AMOUNT is the bond issued amount, logarithmically transformed; $M A T U$ is bond maturity expressed in years; LISTED is a dummy variable for listed bonds; SUBORDINATED is a dummy variable for subordinated bonds; PARENT is a dummy variable for parent issued bonds; INSTUTIONAL is a dummy variable for bond issues targeted at institutional investors; PRIVATE is a dummy variable for privately placed bonds. Standard errors clustered at the issuer level are reported in parentheses. ${ }^{* *}, *^{*}$, and * indicate statistical significance at $1 \%, 5 \%$, and $10 \%$.

\begin{tabular}{|c|c|c|}
\hline Variables & (1) & (2) \\
\hline \multirow[t]{2}{*}{$L P R$} & $0.097^{* * *}$ & $0.072^{* *}$ \\
\hline & {$[0.036]$} & {$[0.032]$} \\
\hline \multirow[t]{2}{*}{$B L R(\%)$} & & $0.116^{* * *}$ \\
\hline & & {$[0.035]$} \\
\hline \multirow[t]{2}{*}{$I N P L(\%)$} & & $0.023^{* * *}$ \\
\hline & & {$[0.005]$} \\
\hline \multirow[t]{2}{*}{$I P L(\%)$} & & $-1.292^{* *}$ \\
\hline & & {$[0.574]$} \\
\hline \multirow[t]{2}{*}{$\operatorname{LRC}(\%)$} & $-0.010^{* *}$ & -0.005 \\
\hline & {$[0.004]$} & {$[0.004]$} \\
\hline \multirow[t]{2}{*}{ LIQ (\%) } & $-0.022^{* * *}$ & $-0.027^{* * *}$ \\
\hline & {$[0.008]$} & {$[0.007]$} \\
\hline \multirow[t]{2}{*}{$L E V$} & 0.034 & 0.027 \\
\hline & {$[0.03]$} & {$[0.032]$} \\
\hline \multirow[t]{2}{*}{$R O A A(\%)$} & 0.256 & 0.272 \\
\hline & {$[0.224]$} & [0.188] \\
\hline \multirow[t]{2}{*}{ ASSETS } & 0.325 & 0.205 \\
\hline & {$[0.23]$} & {$[0.252]$} \\
\hline \multirow[t]{2}{*}{ AMOUNT } & -0.128 & -0.133 \\
\hline & [0.093] & {$[0.092]$} \\
\hline \multirow[t]{2}{*}{$M A T U$} & -0.037 & -0.041 \\
\hline & {$[0.025]$} & {$[0.026]$} \\
\hline \multirow[t]{2}{*}{ LISTED } & $0.453^{* *}$ & $0.432^{* *}$ \\
\hline & {$[0.203]$} & {$[0.202]$} \\
\hline \multirow[t]{2}{*}{ SUBORDINATED } & $1.285^{* * *}$ & $1.250^{* * *}$ \\
\hline & [0.329] & {$[0.325]$} \\
\hline
\end{tabular}


TABLE 8 (Continued)

\begin{tabular}{|lll|}
\hline Variables & $\mathbf{( 1 )}$ & $\mathbf{( 2 )}$ \\
\hline PARENT & $0.399^{* *}$ & $0.384^{* *}$ \\
\hline INSTITUTIONAL & {$[0.179]$} & {$[0.172]$} \\
\hline PRIVATE & 0.203 & 0.199 \\
& {$[0.159]$} & {$[0.147]$} \\
\hline LPR $\times$ LRC & $0.466^{* * *}$ & $0.450^{* * *}$ \\
& {$[0.119]$} & {$[0.117]$} \\
\hline \# of banks & 0.002 & 0.0003 \\
\hline \# of observations & {$[0.002]$} & {$[0.002]$} \\
\hline Adjusted $R$-squared & 14 & 14 \\
\hline Year FE & 3,966 & 3,888 \\
\hline
\end{tabular}

While sovereign debt tensions have clearly increased the cost of bank funding (Albertazzi et al., 2014), unconventional ECB monetary policies have diminished, at least in the short term, perceptions of bank risk. ${ }^{18}$ In particular, ECB interventions can limit the discipline in the bond funding market. Unsecured bond investors, on the other hand, can ensure that banks pay the actual cost of their risk-taking activities, limiting the moral hazard problem. Based on these arguments, it is important to assess changes in investors' risk perception after the sovereign debt crisis to which policy interventions followed. The main purpose is to examine whether the disciplinary response on our forward-looking asset risk variable, reported in Table 7, has changed from the pre- to the post-sovereign debt crisis period. Sovereign tensions were transmitted to Italian banks as a result of the high exposure to Italian sovereign debt. This explains the fact that the sovereign debt crisis had one of the biggest impacts on Italy, with strong tensions in the lending market (Albertazzi et al., 2014) and consequent impact on bank loan portfolios.

To analyze changes in market discipline, we perform a two-stage analysis. First, we test for a structural break to examine whether the sovereign debt crisis has effectively produced a significant shift in investors' perceived bank risk. The Chow test confirms the presence of a structural break consistent with the sovereign debt crisis date (the null hypothesis is rejected at the $1 \%$ level). Second, we re-estimate Equation (1) in the years preceding and following the sovereign debt crisis. The relatively long time frame of this research allows us to make a comparison of the two sub-periods. Columns (1) and (2) of Table 10 report the results of these two sub-periods. For the post-sovereign debt crisis period, column (3) includes an alternative specification of bank funding risk (i.e., NSFR).

\footnotetext{
${ }^{18}$ This can occur through the improved bank funding conditions and reduction in perceptions of sovereign credit risk. With respect to the latter it is important to point out that the reduction in bank funding pressures has: (a) reduced the need for government interventions and (b) improved the economic outlook for the banks. Furthermore, after ECB allotments, Italian banks increased their sovereign debt exposure by purchasing government bonds, which, as a result, has reflected in an improvement in sovereign funding conditions (BIS, 2012).
} 
TABLE 9 The nexus between $L P R$ and $L R C$ - part B

This table reports the results from the regression analysis examining the spread-to-risk relationship of bond spreads. Spread is computed as the difference between the yield to maturity and the corresponding maturitymatch interest rate swap; $L P R$ is the average loan portfolio risk over a 1-year horizon; $B L R$ is the ratio of bad loans to total gross loans; INPL is the ratio of impairment loss on nonperforming loans to total nonperforming loans; IPL is the ratio of impairment loss on performing loans to total performing loans; high.LRC is a dummy variable that takes value 1 when the Loans Rating Coverage Variable (defined as the amount of loans with an assigned rating over total gross loans) is in the fourth quartile of its sample distribution; low.LRC is a dummy variable that takes value 1 when the $L R C$ variable is in the first quartile of its sample distribution; $L I Q$ is the ratio of liquid assets to deposits and short-term funding; $L E V$ is the ratio of total liabilities to total equity; $R O A A$ is the ratio of year-end net income to total average assets; Loans/Fund is the ratio between loans and deposits and short-term funding; ASSETS is the logarithmic transformation of total assets; AMOUNT is the bond issued amount, logarithmically transformed; MATU is bond maturity expressed in years; LISTED is a dummy variable for listed bonds; SUBORDINATED is a dummy variable for subordinated bonds; PARENT is a dummy variable for parent issued bonds; INSTUTIONAL is a dummy variable for bond issues targeted at institutional investors; PRIVATE is a dummy variable for privately placed bonds. Standard errors clustered at the issuer level are reported in parentheses. ${ }^{* *},{ }^{* *}$, and * indicate statistical significance at $1 \%, 5 \%$, and $10 \%$.

\begin{tabular}{|c|c|c|c|c|}
\hline Variables & (1) & (2) & (3) & (4) \\
\hline \multirow[t]{2}{*}{$L P R$} & $0.051^{*}$ & 0.037 & $0.089 * *$ & $0.069^{* *}$ \\
\hline & {$[0.031]$} & {$[0.036]$} & {$[0.038]$} & {$[0.031]$} \\
\hline \multirow[t]{2}{*}{$B L R(\%)$} & & $0.128^{* * *}$ & & $0.119^{* * *}$ \\
\hline & & {$[0.036]$} & & {$[0.038]$} \\
\hline \multirow[t]{2}{*}{$I N P L(\%)$} & & $0.029^{* * *}$ & & $0.028^{* * *}$ \\
\hline & & {$[0.008]$} & & {$[0.008]$} \\
\hline \multirow[t]{2}{*}{$I P L(\%)$} & & -0.934 & & $-1.393^{* * *}$ \\
\hline & & {$[0.642]$} & & {$[0.471]$} \\
\hline \multirow[t]{2}{*}{ High.LRC } & $-1.307^{* * *}$ & $-1.093^{* *}$ & & \\
\hline & {$[0.483]$} & {$[0.500]$} & & \\
\hline \multirow[t]{2}{*}{ Low.LRC } & & & 0.198 & 0.172 \\
\hline & & & {$[0.251]$} & {$[0.210]$} \\
\hline \multirow{2}{*}{ LIQ (\%) } & $-0.021^{* * *}$ & $-0.024^{* * *}$ & $-0.024^{* * *}$ & $-0.027^{* * *}$ \\
\hline & {$[0.008]$} & {$[0.008]$} & [0.009] & {$[0.008]$} \\
\hline \multirow[t]{2}{*}{$L E V$} & 0.036 & 0.032 & 0.045 & 0.035 \\
\hline & {$[0.036)$} & {$[0.028]$} & {$[0.037]$} & {$[0.035]$} \\
\hline \multirow[t]{2}{*}{$R O A A(\%)$} & 0.334 & $0.307^{*}$ & 0.251 & 0.246 \\
\hline & {$[0.243]$} & {$[0.166]$} & {$[0.233]$} & {$[0.232]$} \\
\hline \multirow[t]{2}{*}{ Loans/Fund (\%) } & 0.001 & & & \\
\hline & {$[0.006]$} & & & \\
\hline \multirow[t]{2}{*}{ ASSETS } & 0.221 & 0.199 & $0.399^{*}$ & 0.221 \\
\hline & {$[0.253]$} & {$[0.228]$} & {$[0.210]$} & {$[0.226]$} \\
\hline \multirow[t]{2}{*}{ AMOUNT } & -0.130 & -0.135 & -0.128 & -0.132 \\
\hline & [0.092] & [0.091] & [0.092] & [0.092] \\
\hline
\end{tabular}


TABLE 9 (Continued)

\begin{tabular}{|lllll|}
\hline Variables & $\mathbf{( 1 )}$ & $\mathbf{( 2 )}$ & $\mathbf{( 3 )}$ & $\mathbf{( 4 )}$ \\
\hline MATU & -0.039 & $-0.043^{*}$ & -0.035 & -0.041 \\
& {$[0.025]$} & {$[0.026]$} & {$[0.024]$} & {$[0.026]$} \\
\hline LISTED & $0.468^{* *}$ & $0.429^{* *}$ & $0.467^{* *}$ & $0.421^{* *}$ \\
& {$[0.206]$} & {$[0.201]$} & {$[0.203]$} & {$[0.191]$} \\
\hline SUBORDINATED & $1.257^{* * *}$ & $1.221^{* * *}$ & $1.280^{* * *}$ & $1.249^{* * *}$ \\
\hline PARENT & {$[0.320]$} & {$[0.319]$} & {$[0.327]$} & {$[0.328]$} \\
\hline INSTITUTIONAL & $0.417^{* *}$ & $0.400^{* *}$ & $0.401^{* *}$ & $0.396^{* *}$ \\
& {$[0.182]$} & {$[0.174]$} & {$[0.181]$} & {$[0.184]$} \\
\hline PRIVATE & 0.199 & 0.192 & 0.203 & 0.198 \\
& {$[0.158]$} & {$[0.146]$} & {$[0.161]$} & {$[0.150]$} \\
\hline LPR $\times$ High.LRC & $0.446^{* * *}$ & $0.445^{* * *}$ & $0.468^{* * *}$ & $0.450^{* * *}$ \\
& {$[0.114]$} & {$[0.112]$} & {$[0.118]$} & {$[0.114]$} \\
\hline LPR $\times$ Low.LRC & $0.146^{* *}$ & $0.133^{* *}$ & & \\
\hline \# of banks & {$[0.057]$} & {$[0.062]$} & & -0.021 \\
\hline \# of observations & & & -0.003 & {$[0.029]$} \\
\hline Adjusted $R$-squared & & 14 & 14 & 14 \\
\hline Year FE & 14 & 3,888 & 3,966 & 3,888 \\
\hline & 3,966 & 0.5303 & 0.5256 & 0.5277 \\
\hline
\end{tabular}

For the first period (column (1)), we document the lack of statistical significance of both backward- and forward-looking measures of loan quality. Only the bad loan ratio $(B L R)$ is positive and statistically significant, although only at the $10 \%$ level. This finding is consistent with the fact that the high-risk nature of banks' investments has not been timely assessed by the market. In other words, loan quality does not seem to matter, as investors price only partially loan portfolio riskiness and with a backward-looking view. For the second period (column (2)), we find that our new measure of loan portfolio risk is positive and statistically significant, suggesting that investors reasonably recognize the need to evaluate loan quality using a more accurate and long-term perspective. The sovereign debt crisis has, therefore, marked a significant turning point in market discipline. Despite the reduction in bond issues (especially evident after 2012) ${ }^{19}$ that is consistent with ECB liquidity injections, we find that investors changed the banks' risk dimensions they price. Forward-looking information, which was previously neglected, becomes an important disciplinary channel in the post-sovereign debt crisis period. The market response changes which reflect, at least for our forward-looking variable of asset quality, an improvement in market discipline. This occurs even though ECB 
TA B LE 10 Pre- and post-sovereign debt crisis

This table reports the results from the regression analysis examining the spread-to-risk relationship of bond spreads over two periods: before (column (1)) and after (columns (2) and (3)) the sovereign debt crisis, which occurred on May 2010. Spread is computed as the difference between the yield to maturity and the corresponding maturity-match interest rate swap; $L P R$ is the average loan portfolio risk over a 1-year horizon; $B L R$ is the ratio of bad loans to total gross loans; INPL is the ratio of impairment loss on nonperforming loans to total nonperforming loans; $I P L$ is the ratio of impairment loss on performing loans to total performing loans; $L R C$ is the amount of loans with an assigned rating over total gross loans; LIQ is the ratio of liquid assets to deposits and short-term funding; $L E V$ is the ratio of total liabilities to total equity; $R O A A$ is the ratio of year-end net income to total average assets; NSFR is the Net Stable Funding Ratio computed according to the 2010 version issued by the Basel Committee on Banking Supervision (BCBS); ASSETS is the logarithmic transformation of total assets; AMOUNT is the bond issued amount, logarithmically transformed; $M A T U$ is bond maturity expressed in years; LISTED is a dummy variable for listed bonds; SUBORDINATED is a dummy variable for subordinated bonds; PARENT is a dummy variable for parent issued bonds; INSTUTIONAL is a dummy variable for bond issues targeted at institutional investors; PRIVATE is a dummy variable for privately placed bonds. Standard errors clustered at the issuer level are reported in parentheses. ${ }^{* * *}, * *$, and $*$ indicate statistical significance at $1 \%, 5 \%$, and $10 \%$.

\begin{tabular}{|c|c|c|c|}
\hline & (1) & (2) & (3) \\
\hline Variables & Pre-sovereign crisis & Post-sovereign crisis & Post-sovereign crisis \\
\hline \multirow[t]{2}{*}{$L P R$} & -0.00499 & $0.08169^{* *}$ & $0.07859 * *$ \\
\hline & {$[0.05138]$} & {$[0.04039]$} & {$[0.03776]$} \\
\hline \multirow[t]{2}{*}{$B L R(\%)$} & $0.21396^{*}$ & $0.07736^{*}$ & 0.06998 \\
\hline & {$[0.12618]$} & {$[0.04321]$} & {$[0.04384]$} \\
\hline \multirow[t]{2}{*}{$I N P L(\%)$} & 0.00822 & 0.03174 & 0.03374 \\
\hline & {$[0.01035]$} & {$[0.03553]$} & {$[0.0356]$} \\
\hline \multirow[t]{2}{*}{$I P L(\%)$} & & 0.69948 & 0.51056 \\
\hline & & {$[0.94905]$} & {$[0.79019]$} \\
\hline \multirow[t]{2}{*}{$\operatorname{LRC}(\%)$} & -0.01109 & -0.00791 & -0.00866 \\
\hline & {$[0.00704]$} & {$[0.00586]$} & {$[0.00609]$} \\
\hline \multirow[t]{2}{*}{$L I Q(\%)$} & $0.07703^{* *}$ & $-0.05857^{* * *}$ & $-0.0619 * * *$ \\
\hline & {$[0.03304]$} & {$[0.02253]$} & {$[0.0226]$} \\
\hline \multirow[t]{2}{*}{$L E V$} & -0.01892 & 0.06229 & 0.06479 \\
\hline & {$[0.03687]$} & {$[0.04961]$} & {$[0.04716]$} \\
\hline \multirow[t]{2}{*}{$R O A A(\%)$} & -0.42549 & $1.15711^{* * *}$ & $1.20261^{* *}$ \\
\hline & {$[0.3218]$} & {$[0.50311]$} & {$[0.51815]$} \\
\hline \multirow[t]{2}{*}{ NSFR (\%) } & & & 0.00603 \\
\hline & & & {$[0.00932]$} \\
\hline \multirow[t]{2}{*}{ ASSETS } & 0.35247 & $1.12917^{* * *}$ & $1.2422^{* * *}$ \\
\hline & {$[0.25627]$} & {$[0.40335]$} & {$[0.40279]$} \\
\hline \multirow[t]{2}{*}{ AMOUNT } & $-0.17085^{* *}$ & -0.11265 & -0.11319 \\
\hline & {$[0.08403]$} & {$[0.09245]$} & {$[0.09232]$} \\
\hline \multirow[t]{2}{*}{$M A T U$} & $-0.05101^{* *}$ & -0.02615 & -0.02596 \\
\hline & {$[0.02332]$} & {$[0.05243]$} & {$[0.05275]$} \\
\hline
\end{tabular}


TABLE 10 (Continued)

\begin{tabular}{|llll} 
& $(\mathbf{1})$ & $\mathbf{( 2 )}$ & $\mathbf{( 3 )}$ \\
\hline Variables & Pre-sovereign crisis & Post-sovereign crisis & Post-sovereign crisis \\
\hline LISTED & $1.33438^{* * *}$ & $0.31439^{* *}$ & $0.31578^{* *}$ \\
& {$[0.38564]$} & {$[0.15903]$} & {$[0.15987]$} \\
\hline SUBORDINATED & -0.19189 & $1.57931^{* * *}$ & $1.5815^{* * *}$ \\
& {$[0.17746]$} & {$[0.2436]$} & {$[0.24283]$} \\
\hline PARENT & 0.15995 & $0.50949^{* *}$ & $0.50415^{* *}$ \\
& {$[0.09759]$} & {$[0.24303]$} & {$[0.2445]$} \\
\hline INSTITUTIONAL & 0.11701 & 0.21817 & 0.21774 \\
\hline PRIVATE & {$[0.14347]$} & {$[0.15725]$} & {$[0.15738]$} \\
\hline \# of banks & $0.37058^{* * *}$ & $0.48793^{*}$ & $0.48677^{*}$ \\
\hline \# of observations & {$[0.08424]$} & {$[0.27907]$} & {$[0.27869]$} \\
\hline Adjusted $R$-squared & 13 & 14 & 14 \\
\hline Year FE & 1,714 & 2,174 & 2,174 \\
\hline
\end{tabular}

monetary policies have alleviated the cost-funding repercussions of the sovereign debt crisis on banks. Similar results emerge for column (3), which includes, as an alternative funding risk variable, the NSFR computed based on the 2010 document version issued by the BCBS.

Bank control variables remain broadly unchanged with respect to the baseline model with some exceptions. ROAA is positive and highly statistically significant in the post-sovereign debt crisis period, suggesting that more profitable banks signal higher risk-taking activities, which, in turn, explain higher bond funding costs (Flannery \& Sorescu, 1996). This effect does not hold in the pre-sovereign debt crisis period. During the sovereign crisis, we can infer that profitability tends to be mainly driven by riskier activities than by higher efficiency. Similarly, the variable ASSETS becomes highly significant in the second period, supporting the argument that due to the heightening in risk awareness following the sovereign debt crisis, larger institutions became more exposed to market discipline. The only control variable changing sign with respect to the baseline model is $L I Q$, which, counterintuitively, exhibits a positive impact on bond spread in the pre-sovereign debt crisis, while it becomes again negative in the post-sovereign debt crisis period. Bond control variables exhibit minor differences with respect to the full period analysis.

\section{5 | ROBUSTNESS CHECK}

\subsection{Implicit government guarantees}

A key issue when examining market discipline concerns the market's expectations of government bailouts in case of bank financial distress. This aspect is commonly referred to as implicit government guarantees and it is particularly relevant among large banking groups, the so-called 
'too big to fail.' The existence of government guarantees will reduce investors' incentives to discipline and monitor bank risk-taking behaviors, increasing the moral hazard problem. As previously stated, for market discipline to be effective, unsecured bondholders must perceive that they will bear the risk of losses if the bank experiences solvency issues.

To address the above-mentioned concern, we examine the presence of implicit government guarantees and check the robustness of our results. Following Acharya et al. (2016), we use two measures to assess implicit government guarantees. First, we collect Standard \& Poor's credit ratings. Issuer ratings are a traditional measure of credit risk that assess bank financial commitment after considering all possible external supports that the bank might receive. Second, we gather Moody's bank financial strength (MBFS) ratings as an alternative measure of credit risk. These ratings are 'free-standing' ratings that measure the intrinsic bank financial strength without accounting for potential outside interventions. Differences in bank credit risk between these two ratings provide insight on these agencies' assessment about potential government funding to banks in case of financial distress. Considering that the error term of a regression captures the variability of the dependent variable that is not explained by the independent variables of the model, we regress bank issuer credit ratings on 'free-standing' ratings and use the estimated residuals as a proxy of implicit government guarantees. Specifically, we estimate the following model:

$$
\text { IssuerRating }_{b, t}=\alpha+\beta \text { FreeStandingRating }+\mu_{b}+\mu_{t}+\varepsilon_{b, t}
$$

where Issuer Rating is Standard \& Poor's credit rating and Free Standing Rating is Moody's stand-alone credit rating. From an operational perspective, we transform both ratings (i.e., Issuer Rating and Free Standing Rating) into numbers according to an increasing scale giving higher values to riskier financial institutions. ${ }^{20}$ Here $\mu_{b}$ and $\mu_{b}$ are the bank and time fixed effects, while $\varepsilon_{b, t}$ is the error term that captures the unexplained share and thus proxies implicit government guarantees. Ceteris paribus, higher values of the error term $(\varepsilon)$ reflect higher values of the dependent variable (i.e., higher credit risk) and, therefore, lower implicit government guarantees.

Column (1) of Table 11 reports the results of Equation (1), adding our measure of implicit government guarantees. Columns (2) and (3) of Table 11 document instead the results of the same specification reported in column (1) but estimated for the pre- and post-sovereign debt crisis period. It should be noted that, the reduction in the number of banks analyzed is due to stand-alone ratings being available for only a smaller subset of banks.

The coefficient on Guarantees is always positive and statistically significant, indicating that lower expectations of implicit government guarantees (that is, higher values of the Guarantees variable) increase bank cost of funding. This result is consistent with the presence of implicit government guarantees during the financial crisis and the fact that a reduction in government guarantees increases market participants' incentives to evaluate bank risk-taking activities. Comparing columns (2) and (3), it is important to note that the coefficient on Guarantees is lower in the second period, suggesting that market discipline heightened in the post-sovereign debt crisis period, further supporting prior inference from Table 10. Furthermore, the ASSETS variable has a negative sign in the pre-sovereign debt crisis period but has a positive sign

\footnotetext{
${ }^{20}$ We convert S\&P issuer ratings according to Table 2, while we transform MBFS ratings, which range from A to E, using the following scale: A (bank documents superior financial strength) $=1, \ldots$, E (bank documents very poor financial strength) $=13$.
} 
TA B LE 11 Implicit government guarantees

This table reports the results from the regression analysis examining the spread-to-risk relationship of bond spreads over three periods: the full period, from 2007 to mid-2014 (column (1)), the period before (column (2)) and after (column (3)) the sovereign debt crisis, which occurred on May 2010. Spread is computed as the difference between the yield to maturity and the corresponding maturity-match interest rate swap; $L P R$ is the average loan portfolio risk over a 1-year horizon; BLR is the ratio of bad loans to total gross loans; INPL is the ratio of impairment loss on nonperforming loans to total nonperforming loans; IPL is the ratio of impairment loss on performing loans to total performing loans; $L R C$ is the amount of loans with an assigned rating over total gross loans; $L E V$ is the ratio of total liabilities to total equity; $R O A A$ is the ratio of year-end net income to total average assets; Loans/Fund is the ratio between loans and deposits and short-term funding; ASSETS is the logarithmic transformation of total assets; AMOUNT is the bond issued amount, logarithmically transformed; $M A T U$ is bond maturity expressed in years; LISTED is a dummy variable for listed bonds; SUBORDINATED is a dummy variable for subordinated bonds; PARENT is a dummy variable for parent issued bonds; INSTUTIONAL is a dummy variable for bond issues targeted at institutional investors; PRIVATE is a dummy variable for privately placed bonds; Guarantees captures implicit government guarantees, where lower values indicate higher perceived government guarantees. Standard errors clustered at the issuer level are reported in parentheses. ${ }^{* * *}$, **, and * indicate statistical significance at $1 \%, 5 \%$, and $10 \%$.

\begin{tabular}{|c|c|c|c|}
\hline Variables & $\begin{array}{l}\text { (1) } \\
\text { Full }\end{array}$ & $\begin{array}{l}\text { (2) } \\
\text { Pre-sovereign crisis }\end{array}$ & $\begin{array}{l}\text { (3) } \\
\text { Post-sovereign crisis }\end{array}$ \\
\hline$L P R$ & $\begin{array}{l}0.1034 * * * \\
{[0.03315]}\end{array}$ & $\begin{array}{l}-0.00273 \\
{[0.02506]}\end{array}$ & $\begin{array}{l}0.09129 * * * \\
{[0.03704]}\end{array}$ \\
\hline$I N P L(\%)$ & $\begin{array}{l}0.00405 \\
{[0.00903]}\end{array}$ & $\begin{array}{l}0.00757 \\
{[0.02763]}\end{array}$ & \\
\hline$I P L(\%)$ & $\begin{array}{l}-2.38179^{* * *} \\
{[0.92357]}\end{array}$ & $\begin{array}{l}1.06878 \\
{[1.80562]}\end{array}$ & $\begin{array}{l}0.03841 \\
{[1.34991]}\end{array}$ \\
\hline $\operatorname{LRC}(\%)$ & $\begin{array}{l}-0.0037 \\
{[0.00511]}\end{array}$ & $\begin{array}{l}0.00047 \\
{[0.01212]}\end{array}$ & $\begin{array}{l}-0.00813 \\
{[0.00612]}\end{array}$ \\
\hline$L E V$ & $\begin{array}{l}0.02752 \\
{[0.03937]}\end{array}$ & $\begin{array}{l}-0.00459 \\
{[0.02948]}\end{array}$ & \\
\hline$R O A A(\%)$ & $\begin{array}{l}0.16091 \\
{[0.16036]}\end{array}$ & $\begin{array}{l}0.14411 \\
{[0.2393]}\end{array}$ & $\begin{array}{l}0.60641 \\
{[1.13432]}\end{array}$ \\
\hline Loans/Fund (\%) & $\begin{array}{l}-0.00058 \\
{[0.0058]}\end{array}$ & & \\
\hline ASSETS & $\begin{array}{l}0.60118^{* * * *} \\
{[0.22721]}\end{array}$ & $\begin{array}{l}-0.3102^{* * *} \\
{[0.09177]}\end{array}$ & $\begin{array}{l}3.12414^{* *} \\
{[1.33107]}\end{array}$ \\
\hline AMOUNT & $\begin{array}{l}-0.17499^{* *} \\
{[0.08886]}\end{array}$ & $\begin{array}{l}-0.17806^{* *} \\
{[0.08728]}\end{array}$ & $\begin{array}{l}-0.19232^{* *} \\
{[0.08159]}\end{array}$ \\
\hline$M A T U$ & $\begin{array}{l}-0.03168^{*} \\
{[0.01767]}\end{array}$ & $\begin{array}{l}-0.06899^{* * *} \\
{[0.02057]}\end{array}$ & $\begin{array}{l}0.00296 \\
{[0.02009]}\end{array}$ \\
\hline LISTED & $\begin{array}{l}0.69846^{* * *} \\
{[0.26544]}\end{array}$ & $\begin{array}{l}1.21591^{* * *} \\
{[0.38328]}\end{array}$ & $\begin{array}{l}0.57914^{* *} \\
{[0.24548]}\end{array}$ \\
\hline SUBORDINATED & $\begin{array}{l}0.85686^{* * *} \\
{[0.3127]}\end{array}$ & $\begin{array}{l}-0.1299 \\
{[0.16612]}\end{array}$ & $\begin{array}{l}1.57056^{* * *} \\
{[0.17873]}\end{array}$ \\
\hline
\end{tabular}


TABLE 11 (Continued)

\begin{tabular}{|llll} 
& $\mathbf{( 1 )}$ & $\mathbf{( 2 )}$ & $\mathbf{( 3 )}$ \\
\hline Variables & Full & Pre-sovereign crisis & Post-sovereign crisis \\
\hline PARENT & $0.41397^{* *}$ & $0.2495^{* *}$ & $0.56989^{* * *}$ \\
& {$[0.16368]$} & {$[0.10185]$} & {$[0.11781]$} \\
\hline INSTITUTIONAL & 0.07907 & 0.02526 & -0.02717 \\
\hline PRIVATE & {$[0.1599]$} & {$[0.15105]$} & {$[0.10986]$} \\
\hline Guarantees & $0.52247^{* * *}$ & $0.47661^{* * *}$ & $0.57259^{* * *}$ \\
& {$[0.05732]$} & {$[0.08818]$} & {$[0.18656]$} \\
\hline \# of banks & $0.18662^{* * *}$ & $0.5095^{*}$ & $0.17864^{* * *}$ \\
\hline \# of observations & {$[0.05429]$} & {$[0.28342]$} & {$[0.04623]$} \\
\hline Adjusted $R$-squared & 8 & 7 & 8 \\
\hline Year FE & 2,910 & 1,505 & 1,405 \\
\hline
\end{tabular}

afterward. Both effects are statistically significant. This is consistent with the argument that, in the second period, market discipline strengthened to the extent that the TBTF status, which generally characterizes the largest banking groups, weakened.

Consistent with the previous results, our forward-looking measure on loan quality is positive and statistically significant in the full model (column (1)) and in the post-sovereign debt crisis period (column (3)). Controlling for the presence of implicit government guarantees, we therefore provide evidence that our new measure of loan quality is priced by the bond market. We also observe a risk-perception change in bank loan portfolios by the market following the sovereign debt crisis.

\section{6 | CONCLUSIONS}

In this paper we examine the sensitivity of bond spreads to bank loan quality over the 2007 to mid-2014 period. Due to data limitations, many of the existing studies evaluate bank loan quality using traditional accounting-based indicators, which have shortcomings. They are backward-looking indicators, making them less informative to evaluate the presence and strength of market discipline. To address this issue, we examine a new forward-looking indicator of loan risk using external ratings assigned by external rating agencies to credit risk exposures and disclosed only by Italian banks as required by national financial reporting regulation.

Our main finding shows that our forward-looking measure of loan risk is informative and incrementally priced by the bond market, even after controlling for a comprehensive set of traditional loan quality variables, and standard risk controls. In order to study changes in market discipline, which are likely to have occurred during our time frame which was subject to adverse market conditions, we also perform a structural break analysis on May 2010. This date was set as the sovereign debt crisis date from which, later on, ECB unconventional monetary 
policies followed. Results show the presence of a significant structural break, which motivated us to separately analyze the period before and after the sovereign debt crisis. The analysis for the two sub-periods revealed some interesting findings. Consistent with the results of Stephanou (2010), we find that market discipline has failed to timely assess bank loan risk. Specifically, we do not find evidence of significant early warning signals by the market in the presovereign debt crisis period. If investors had timely evaluated risk-taking behaviors, the distress of many banks could have probably been avoided. However, this does not seem to be the case in Italy (and worldwide according to prior research). Once the sovereign debt crisis took hold, we find that the market played its role, extensively pricing our forward-looking measure on loan risk. As a check of the robustness of our results, we account for implicit government guarantees constructing a proxy using both traditional issuer ratings and 'free-standing' ratings.

The literature on market discipline has extensively examined bond spread sensitivity, positing that informational transparency and high-quality reporting information play a fundamental role in enhancing the complementary role of the market in disciplining banks. The relevance of information disclosure is further strengthened when looking at bank loans, which are commonly considered informationally opaque. Our study extends prior research by introducing a new measure of loan quality, with a forward-looking focus. We therefore complement and extend the literature by examining a previously unexplored channel for investors to discipline banks. Overall, we find that this new measure improves market discipline in the post-sovereign debt crisis period. Therefore, this research sheds some light on the channels by which market discipline can operate and suggests that other countries should consider requiring disclosure of the information embedded in this indicator.

With respect to limitations of our study, our main variable of interest covers only a portion of the total credit exposure. Therefore, our forward-looking measure probably underestimates the bank's true credit risk. Consistent with this conjecture, we find that our results are stronger for banks which have a greater proportion of their loan portfolio covered by external credit ratings. Finally, our study focuses on the largest Italian banks. Since the forward-looking information is mandated only for Italian banks, and banks in other countries do not systematically disclose this information, a cross-country comparison is not possible. With the introduction of accounting standard IFRS 9 in January 2018, which replaced the incurred loss with the expected loss model (IFRS, 2014), future research can extend the analysis to multiple countries and examine potential country-of-origin heterogeneous reactions.

\section{REFERENCES}

Acharya, V. V., Anginer, D., \& Warburton, A. J. (2016). The end of market discipline? Investor expectations of implicit government guarantees (SSRN Working Paper Series).

Albertazzi, U., Ropele, T., Sene, G., \& Signoretti, F. M. (2014). The impact of the sovereign debt crisis on the activity of Italian banks. Journal of Banking \& Finance, 46, 387-402.

Avery, R. B., Belton, T. M., \& Goldberg, M. A. (1988). Market discipline in regulating bank risk: New evidence from the capital markets. Journal of Money, Credit and Banking, 20, 597-610.

Balasubramnian, B., \& Cyree, K. B. (2014). Has market discipline on banks improved after the Dodd-Frank Act? Journal of Banking \& Finance, 41, 155-166.

Bank for International Settlements (BIS). (2012). European Bank funding and deleveraging. BIS Quarterly Review, 1-12.

BCBS. (2010). Basel III: International framework for liquidity risk measurement, standards and monitoring, s.l. Basel, Switzerland: Bank for International Settlements.

Benink, H., \& Wihlborg, C. (2002). The new Basel Capital Accord: Making it effective with stronger market discipline. European Financial Management, 8, 103-115. 
Berger, A., Davies, S., \& Flannery, M. (2000). Comparing market and supervisory assessments of bank performance: Who knows what when? Journal of Money, Credit and Banking, 32, 641-667.

Blanco, R., Brennan, S., \& Marsh, I. W. (2005). An empirical analysis of the dynamic relation between investment-grade bonds and credit default swaps. The Journal of Finance, 55, 2255-2281.

Crespi, F., Giacomini, E., \& Mascia, D. V. (2019). Bail-in rules and the pricing of Italian bank bonds. European Financial Management, 25, 1-27.

DeYoung, R., Hughes, J., \& Moon, C.-G. (2001). Efficient risk-taking and regulatory covenant enforcement in a deregulated banking industry. Journal of Economics and Business, 53, 255-282.

Flannery, M. J., \& Sorescu, S. M. (1996). Evidence of bank market discipline in subordinated debenture yields: 1983-1991. The Journal of Finance, 51, 1347-1377.

Gao, Y., Liao, S., \& Wang, X. (2018). Capital markets' assessment of the economic impact of the Dodd-Frank Act on systematically important financial firms. Journal of Banking \& Finance, 86, 204-223.

Gorton, G., \& Santomero, A. M. (1990). Market discipline and bank subordinated debt: Note. Journal of Money, Credit and Banking, 22, 119-128.

Grasso, R., Linciano, N., Pierantoni, L., \& Siciliano, G. (2010). Bond issued by Italian banks: Risk and return characteristics (CONSOB Working Papers 67), pp. 1-32.

Gropp, R., Gruendl, C., \& Guettler, A. (2014). The impact of public guarantees on bank risk-taking: Evidence from a natural experiment. Review of Finance, 18, 457-488.

Hasan, I., \& Wall, L. (2004). Determinants of the loan loss allowance: Some cross-country comparison. The Financial Review, 39, 129-152.

Hull, J., Predescu, M., \& White, A. (2004). The relationship between credit default swap spreads, bond yields, and credit rating announcements. Journal of Banking and Finance, 28, 2789-2811.

IFRS. (2014). IASB completes reform of financial instruments accounting [Online]. Retrieved from http://www. ifrs.org/news-and-events/2014/07/iasb-completes-reform-of-financial-instruments-accounting/

Jagtiani, J., Kaufman, G., \& Lemieux, C. (2002). The effect of credit risk on bank and bank holding company bond yields: Evidence from the post-FDICIA period. The Journal of Financial Research, 25, 559-575.

Krylova, E. (2016). Determinants of euro-denominated corporate bond spreads (Working Paper Series No. 1912).

Morgan, D. P., \& Stiroh, K. J. (2000). Bond market discipline of banks: Is the market tough enough? Federal Reserve Bank of New York Staff Report, 95.

Morgan, D. P., \& Stiroh, K. J. (2001). Market discipline of banks: The asset test. Journal of Financial Services Research, 20, 195-208.

Ricci, O. (2015). The impact of monetary policy announcements on the stock price of large European banks during the financial crisis. Journal of Banking \& Finance, 52, 245-255.

Sironi, A. (2003). Testing for market discipline in the European banking industry: Evidence from subordinated debt issues. Journal of Money, Credit and Banking, 35, 443-472.

Stephanou, C. (2010). Rethinking market discipline in banking: Lessons from the financial crisis (Policy Research Working Paper).

How to cite this article: Simion G, Cavezzali E, Nathan S, Rigoni U. Market discipline on bank bond issues through the lens of a new forward-looking measure of loan quality. Eur Financ Manag. 2020;26:1350-1384. https://doi.org/10.1111/eufm.12262 


\section{APPENDIX}

Examples of External Ratings

\begin{tabular}{lrrrrrr} 
& \multicolumn{7}{c}{ External rating classes } \\
\cline { 2 - 7 } & Class 1 & Class 2 & Class 3 & Class 4 & Class 5 & Class 6 \\
\hline A. On-balance sheet exposures & $\mathbf{7 , 7 1 5}$ & $\mathbf{5 2 , 2 5 3}$ & $\mathbf{6 1 , 0 2 3}$ & $\mathbf{4 , 5 6 6}$ & 11,685 & $\mathbf{2 9 , 2 1 5}$ \\
B. Derivatives & $\mathbf{6 0 3}$ & $\mathbf{2 , 6 8 7}$ & $\mathbf{5 , 3 2 4}$ & 247 & $\mathbf{4 1 6}$ & 173 \\
B.1. Financial derivatives & 602 & 2,653 & 5,231 & 247 & 416 & 173 \\
B.2. Credit derivatives & 1 & 34 & 93 & - & - & - \\
C. Guarantees given & $\mathbf{4 , 1 0 9}$ & $\mathbf{5 , 8 9 2}$ & $\mathbf{4 , 4 4 3}$ & $\mathbf{5 0 1}$ & $\mathbf{2 6 1}$ & $\mathbf{5 1 0}$ \\
D. Commitments to lend funds & $\mathbf{3 , 0 5 4}$ & $\mathbf{8 5 , 8 0 0}$ & 17,622 & 709 & $\mathbf{2 6 3}$ & $\mathbf{7 2 5}$ \\
E. Other & - & - & 2,232 & - & - & - \\
Total & 15,481 & 146,632 & 90,644 & 6,023 & 12,625 & $\mathbf{3 0 , 6 2 3}$ \\
\hline
\end{tabular}

FI G URE A1 Intesa SanPaolo SpA (extract from 2012 Annual Report). Classification of exposures based on external ratings - breakdown of on- and off-balance sheet credit exposures by external rating classes (millions of EURO)

\begin{tabular}{|lrrrrrr|}
\hline & \multicolumn{5}{c|}{ AMOUNTS AS AT 12.31.2012 } \\
\cline { 2 - 7 } EXP0SuRES & CLASS 1 & CLASS 2 & CLASS 3 & CLASS 4 & CLASS 5 & CLASS 6 \\
\cline { 2 - 7 } & \multicolumn{6}{c|}{ EXTERNAL RATING CLASSES } \\
\hline A. On-Balance Sheet exposures & $66,458,255$ & $64,124,071$ & $78,012,213$ & $46,124,289$ & $28,679,622$ & $48,827,035$ \\
\hline B. Derivative contracts & $12,070,267$ & $21,449,552$ & $12,175,355$ & $4,320,363$ & $4,169,137$ & 495,326 \\
\hline B.1 Financial derivative contracts & $11,797,220$ & $20,925,559$ & $11,943,039$ & $4,203,304$ & $4,060,952$ & 491,463 \\
\hline B.2 Credit derivative contracts & 273,047 & 523,993 & 232,316 & 117,059 & 108,185 & 3,863 \\
\hline C. Guarantees given & $1,427,074$ & $9,114,542$ & $8,773,720$ & $4,810,606$ & $1,020,986$ & $1,919,020$ \\
\hline $\begin{array}{l}\text { D. Other commitments to } \\
\text { disburse funds }\end{array}$ & $4,120,554$ & $12,400,993$ & $8,978,320$ & $10,171,870$ & $6,156,621$ & $1,744,803$ \\
\hline E. Other & 49,191 & 551,086 & $2,524,890$ & 3,214 & 516,870 & - \\
\hline Total & $84,125,341$ & $107,640,244$ & $110,464,498$ & $65,430,342$ & $40,543,236$ & $52,986,184$ \\
\hline
\end{tabular}

F I G U RE A2 UniCredit SpA (extract from 2012 Annual Report). Classification of exposures based on external ratings - breakdown of on- and off-balance sheet credit exposures by external rating classes (thousands of EURO) 